\title{
The largest European theropod dinosaurs: Remains of a gigantic megalosaurid and giant theropod tracks from the Kimmeridgian of Asturias, Spain
}

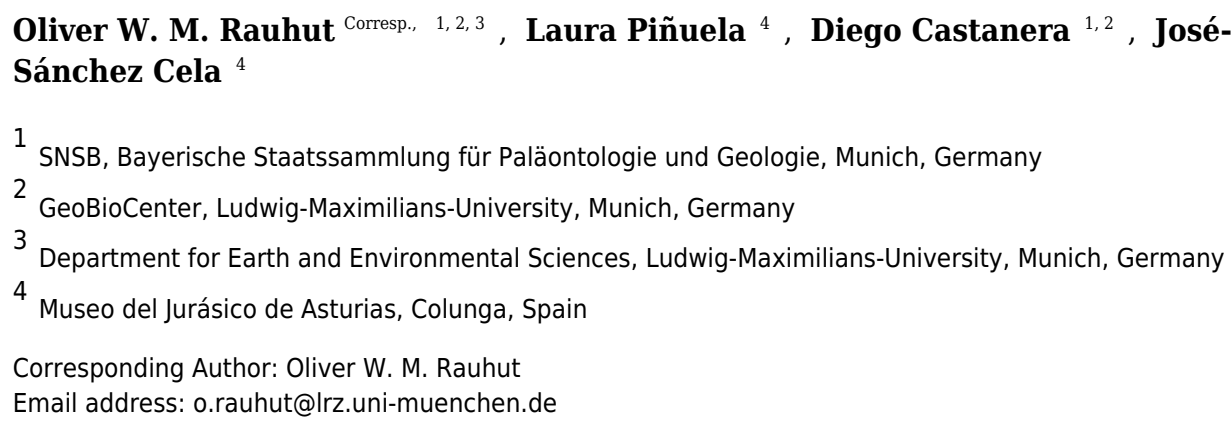

The Kimmeridgian Vega, Tereñes and Lastres formations of Asturias have yielded a rich vertebrate fauna, represented by both abundant tracks and osteological remains. However, skeletal remains of theropod dinosaurs are rare, and the diversity of theropod tracks has only partially been documented in the literature. Here we describe the only nondental osteological theropod remain recovered so far, an isolated anterior caudal vertebra, as well as the largest theropod tracks found. The caudal vertebra can be shown to represent a megalosaurine megalosaurid and represents the largest theropod skeletal remain described from Europe so far. The tracks are also amongst the largest theropod footprints reported from any setting and can be assigned to two different morphotypes, one being characterized by its robustness and a weak mesaxony, and the other characterized by a strong mesaxony, representing a more gracile trackmaker. We discuss the recently proposed distinction between robust and gracile large to giant theropod tracks and their possible trackmakers during the Late Jurassic-Berriasian. In the absence of complete pedal skeletons of most basal tetanurans, the identity of the maker of Jurassic giant theropod tracks is difficult to establish. However, the notable robustness of megalosaurine megalosaurids fits well with the described robust morphotypes, whereas more slender large theropod tracks might have been made by a variety of basal tetanurans, including allosaurids, metriocanthosaurids or afrovenatorine megalosaurids, or even exceptionally large ceratosaurs. Concerning osteological remains of large theropods from the Late Jurassic of Europe, megalosaurids seem to be more abundant than previously recognized and occur in basically all Jurassic deposits where theropod remains have been found, whereas allosauroids seem to be represented by allosaurids in Western Europe and metriacanthosaurids in more eastern areas. Short-term fluctuations in sea 
level might have allowed exchange of large theropods between the islands that constituted Europe during the Late Jurassic. 
1 The largest European theropod dinosaurs: Remains of a gigantic megalosaurid and giant

2 theropod tracks from the Kimmeridgian of Asturias, Spain

3

7 Oliver W. M. Rauhut ${ }^{1,2,3}$, Laura Piñuela ${ }^{4}$, Diego Castanera ${ }^{1,2}$, José-Carlos García-Ramos ${ }^{4}$, and 8 Irene Sánchez Cela ${ }^{4}$

12 'SNSB - Bayerische Staatssammlung für Paläontologie und Geologie, Munich, Germany

$13{ }^{2}$ GeoBioCenter, Ludwig-Maximilians-University, Munich, Germany

$14{ }^{3}$ Department for Earth- and Environmental Sciences, Ludwig-Maximilians-University, Munich, 15 Germany

16 Museo del Jurásico de Asturias, Colunga, Spain

19 Corresponding author:

20 Oliver W. M. Rauhut

21 Richard-Wagner-Str. 10

2280333 Munich

23 email: o.rauhut@|rz.uni-muenchen.de 
26 Abstract

27 The Kimmeridgian Vega, Tereñes and Lastres formations of Asturias have yielded a rich

28 vertebrate fauna, represented by both abundant tracks and osteological remains. However,

29 skeletal remains of theropod dinosaurs are rare, and the diversity of theropod tracks has only

30 partially been documented in the literature. Here we describe the only non-dental osteological

31 theropod remain recovered so far, an isolated anterior caudal vertebra, as well as the largest

32 theropod tracks found. The caudal vertebra can be shown to represent a megalosaurine

33 megalosaurid and represents the largest theropod skeletal remain described from Europe so far.

34 The tracks are also amongst the largest theropod footprints reported from any setting and can be assigned to two different morphotypes, one being characterized by its robustness and a weak mesaxony, and the other characterized by a strong mesaxony, representing a more gracile trackmaker. We discuss the recently proposed distinction between robust and gracile large to giant theropod tracks and their possible trackmakers during the Late Jurassic-Berriasian. In the absence of complete pedal skeletons of most basal tetanurans, the identity of the maker of Jurassic giant theropod tracks is difficult to establish. However, the notable robustness of megalosaurine megalosaurids fits well with the described robust morphotypes, whereas more

42 slender large theropod tracks might have been made by a variety of basal tetanurans, including 43 allosaurids, metriocanthosaurids or afrovenatorine megalosaurids, or even exceptionally large 44 ceratosaurs. Concerning osteological remains of large theropods from the Late Jurassic of Europe, megalosaurids seem to be more abundant than previously recognized and occur in basically all Jurassic deposits where theropod remains have been found, whereas allosauroids seem to be represented by allosaurids in Western Europe and metriacanthosaurids in more eastern areas. Short-term fluctuations in sea level might have allowed exchange of large theropods between the islands that constituted Europe during the Late Jurassic. 
In the Late Jurassic, Europe was an assemblage of numerous smaller to large islands, separated by shallow epicontinental seas (Cosentino et al., 2010: fig. 7). Apart from the Fennoscandian shield, representing the largest continental mass in north-eastern Europe, larger landmasses included, from east to west, the Bohemian Massif (approximately where the Czech Republic lies today), the London-Brabant Massif and the Rhenian Isle (extending from the area around London to the lower Rhine embayment), the Massif Central (south-central France), the Armorican Massif (mainly the Bretagne today), the Irish Massif in the north-west, and the Iberian Massif (Portugal and parts of western Spain). During parts of the Late Jurassic, the London-Brabant-Rhenian Massif and the Bohemian Massif might have been connected in the north, and the Armorican Massif might have partially had a connection with the Massif Central (Thierry et al. 2000; Meyer, 2012). All of these landmasses certainly possessed a fauna of terrestrial vertebrates, but little is still known about many of these faunas. Apart from the record of the Iberian Peninsula, in which abundant terrestrial vertebrates are mainly found in Late Jurassic terrestrial to transitional sediments of the Lusitanian (see Mocho et al., 2017, and references therein) Maestrazgo and South Iberian basins (Royo-Torres et al., 2009; Aurell et al., 2016; Campos-Soto et al., 2017), most records of Late Jurassic dinosaurs from Europe come from shallow marine sediments, such as the famous lithographic limestones of southern Germany (Rauhut \& Tischlinger, 2015; Tischlinger et al., 2015), the Upper Oxford Clay and Kimmeridge Clay of England (see Benson, 2008a; Benson \& Barrett, 2009; Barrett et al., 2010; Carrano et al., 2012), the marine carbonates at Oker, Germany (Sander et al., 2006), the Reuchenette Formation of Switzerland (Meyer \& Thüring, 2003), the laminated limestones of Canjuers (Peyer, 2006), or the Calcaire de Cleval Formation in eastern France (Mannion et al., 2017). Interestingly, the sparse evidence from these more eastern occurrences seems to indicate some differences with the fauna from western Iberia. Whereas the latter fauna is closely comparable to the contemporaneous fauna of the Morrison Formation of western North America (Mateus, 2006), with even several shared genera being present (Pérez-Moreno et al., 1999; Antunes \& Mateus, 2003; Escaso et al., 2007; Malafaia et al., 2007, 2015, 2017a; Hendrickx \& Mateus, 2014), at least the theropod fauna from more eastern European localities seems to show some Asian influence, with the metricanthosaurid Metriacanthosaurus from the Oxfordian of 
81 England (Huene, 1926; Walker, 1964; Carrano et al., 2012), possible metriacanthosaurid teeth in 82 the Kimmeridgian of northern Germany (Gerke \& Wings, 2016), and compsognathid and 83 paravian theropods from the Kimmeridgian-Tithonian of the Solnhofen Archipelago (Ostrom, 84 1978; Wellnhofer, 2008; Tischlinger et al, 2015; Foth \& Rauhut, 2017).

85 Further evidence on the Late Jurassic dinosaur fauna from Europe comes from dinosaur 86 tracksites. Abundant dinosaur tracks are known from the Iberian Peninsula, from different sites within the Lusitanian Basin (Santos et al. , 2008; Mateus and Milàn, 2010), the Villar de Arzobispo Formation of Teruel Province in Spain (e.g. Canudo et al., 2005; Aurell et al., 2016; Campos-Soto et al., 2017), and from the „dinosaur coast“ of Asturias, Spain (García-Ramos et al., 2006; Piñuela Suárez, 2015). Tracksites are also known from the Late Jurassic of France (e.g. Mazin et al., 1997, 2016, 2017; Moreau et al., 2017), Germany (Kaever \& Lapparent, 1974; Diedrich, 2011; Lallensack et al., 2015), Italy (Conti et al., 2005), and Poland (Gierlinski \& Niedzwiedzki, 2002; Gierlinski et al., 2009), but the largest Late Jurassic track bearing area is certainly that of the Jura mountains of Switzerland (e.g: Marty et al., 2007, 2017; Razzolini et al., 2017; Castanera et al., 2018). Although the identification of theropod tracks to certain clades remains problematic (see also below), these occurrences can give important insights into theropod diversity and community structure. Apart from the abundant record from the Lusitanian, South Iberian and Maestrazgo Basins, Late Jurassic dinosaur remains, both body fossils and tracks, have also been reported from the Kimmeridgian Vega, Tereñes and Lastres Formations of Asturias, Spain (García-Ramos et al., 2006). In the Late Jurassic, Asturias lay between the Lusitanian Basin and the Armorican Massif, either as part of smaller islands (Cosentino et al. 2010), or as part of the Iberian Massif (Thierry et al., 2000), and its fauna is thus of great interest for understanding European Late Jurassic dinosaur biogeography. Dinosaurs from these units, principally from the Vega and Lastres formations, include mainly ornithischians, with stegosaurs (Ruiz-Omeñaca et al., 2009a, 2013) and ornithopods (Ortega et al., 2006; Ruiz-Omeñaca et al., 2007, 2009b, 2010, 2012) having

107 been reported. Sauropods are rare and include remains of a turiasaur (Canudo et al., 2010) and a 108 diplodocid (Ruiz-Omeñaca et al., 2008). Theropod remains are also rare and consist mainly of 109 isolated teeth (Canudo \& Ruiz-Omeñaca, 2003; Ruiz-Omeñaca et al., 2009c). The only skeletal 110 remain of a theropod is a large anterior caudal vertebra, which was briefly described by Martínez 111 et al. (2000) and referred to an unspecified ceratosaur (see also Canudo \& Ruiz-Omeñaca, 2003). 
112 This specimen, which is remarkable for its extremely large size, is re-evaluated here.

113 Furthermore, the Kimmeridgian of Asturias has yielded a rich dinosaur track record (García-

114 Ramos et al., 2006; Milàn et al., 2006; Avanzini et al., 2008; 2012; Lockley et al., 2008; Piñuela

115 Suárez, 2015; Castanera et al., 2016; Piñuela et al., 2016), including isolated tracks of giant

116 theropods (Piñuela Suárez, 2015), which are also documented here.

117

118 Geological setting

119 The main and best-exposed Jurassic outcrops in the Asturias region extend along the sea cliffs

120 between Gijón and Ribadesella localities (Fig. 1). The Jurassic rocks in the eastern part of

121 Asturias overlie diverse Variscan and Permian-Triassic units and can be grouped into two main

122 lithologically and environmentally characterized units. The lower one is predominantly made up

123 of carbonate rocks of littoral-evaporitic (Gijón Formation) and open marine origin (Rodiles

124 Formation). The upper unit mainly comprises siliciclastic rocks of fluvial (Vega Formation),

125 restricted marine (shelf lagoon) and coastal (fluvial-dominated lagoonal deltas) origin,

126 respectively represented by the Tereñes and Lastres formations (Fig. 2A).

127 The Vega Formation, with an estimated thickness of $150 \mathrm{~m}$, consists of alternating white, pale

128 grey and reddish sandstones and red mudstones with several sporadic conglomeratic beds

129 typically arranged in minor finnig-upward cycles within a major cycle of the same character

130 (Fig. 2B). These rocks represent fluvial deposits formed by ephemeral and highly sinuous

131 streams separated by extensive floodplains on which calcareous palaeosols (calcretes) developed

132 (García-Ramos et al., 2010a; Arenas et al., 2015). Based on datations with ostracods and pollen

133 and spores, the age of the Vega Formation is probably Kimmeridgian (Schudack and Schudack,

134 2002; Barrón, 2010). The climate during sediment deposition represents warm and semi-arid

135 conditions with a strongly seasonal precipitation regime, as indicated by the local presence of

136 gypsum crystals and veins, the palynological composition (Barrón, 2010) and the most frequent

137 palaeosol varieties (Gutierrez and Sheldon, 2012).

138 Fossil prospecting in the Vega Formation type locality, along the coast $6 \mathrm{~km}$ west of Ribadesella

139 town (Fig.1), yielded the theropod caudal vertebra documented in this study. The fossil bone

140 occurred in a $0.65 \mathrm{~m}$ thick grey bed of polygenic calcareous microconglomerate (see asterisk in

141 Fig. 2B), which includes mainly carbonate clasts from underlying marine Jurassic units (Gijón

142 and Rodiles formations), together with intraformational limestone and lutitic fragments from the 
143 Vega Formation. The calcareous microconglomerate passes upwards to a cross-bedded

144 sandstone. Both lithologies are arranged in at least two finning-upwards channelised levels,

145 showing rapid lateral variations in both thickness and grain-sizes.

146 The vertebrate bone bed represents an amalgamation of small lenticular channels (scours)

147 showing several episodes of lateral accretion. Their origin is related to channelised flows

148 produced by extreme flooding events associated with heavy rainfall periods. These high

149 discharge processes are probably supplied by the rapid recharge of water springs from an

150 uppermost Triassic-Lower Jurassic rock aquifer emerging from a nearby fault-controlled

151 calcareous relief located to the south (García-Ramos et al., 2010a; Arenas et al., 2015; Lozano et

152 al., 2016).

153 A tip of a large theropod tooth (MUJA-1226) from the same level as the vertebra described here was

154 reported by Martínez et al. (2000) and described in more detail by Ruiz-Omeñaca et al. (2009c). This

155 crown tip is strongly labiolingually compressed, shows centrally placed, serrated carinae, mesiodistally

156 long, rectangular denticles, antapically directed interdenticular sulci, and an anastomosing enamel texture

157 (Fig. 3; see Ruiz-Omeñaca et al., 2009c). All of these characters are found in megalosaurid teeth, such as

158 teeth of Torvosaurus (Hendrickx et al., 2015), so this specimen most probably represents a megalosaurid.

159 A smaller theropod tooth was also found in this locality (MUJA-1018; Ruiz-Omeñaca et al.,

160 2009). The same level also included some small oncoids, vegetal remains, turtle fragments,

161 crocodile teeth (Ruiz-Omeñaca, 2010), and a sauropod caudal vertebrae (MUJA-0650), as well

162 as poorly-preserved quadrupedal dinosaur footprints, which have not been mentioned or

163 described in the literature so far.

164 The Lastres Formation is about $400 \mathrm{~m}$ thick unit and consists of grey sandstones, lutites and

165 marls with occasional conglomeratic levels (Fig. 2A). The depositional environment was

166 characterised by a succession of fluvial-dominated lagoonal deltas. The main deposits include

167 prodelta, crevasse-splay, levee, distributary channel, delta front, interdistributary bay and delta-

168 abandonment facies (Avanzini et al., 2005; García-Ramos et al., 2006; 2010b). Within the

169 Lastres Formation, several short-term transgressive events are recorded by muddy and calcareous

170 laterally extensive shell beds with abundant brackish-water bivalves and gastropods. This

171 formation has provided numerous tracks, not only belonging to dinosaurs, but also to pterosaurs,

172 crocodiles, turtles and lizards (García-Ramos et al., 2006; Piñuela Suárez, 2015). The footprints

173 here studied were found as loose and isolated sandstone casts on the sea cliffs, thus no precise 
174 descriptions of the levels are provided, but most of the Lastres Formation theropod tracks are 175 related to crevasse-splay facies.

176

177 Institutional abbreviations. BYU, Brigham Young University, Provo, USA; IVPP; Institute of 178 Vertebrate Paleontology and Paleoanthropology, Beijing, China; MOR, Musem of the Rockies, 179 Bozeman, USA; MUJA, Museo del Jurásico de Asturias, Colunga, Spain; NHMUK, Natural

180 History Museum, London, UK; OUMNH, Oxford University Museum of Natural History, 181 Oxford, UK

182

183

DESCRIPTION

184

185 Osteological remains

186 The vertebra MUJA-1913 is a large anterior caudal vertebra that has most of the centrum and the

187 base of the neural arch preserved (Fig. 4); the zygapophyses, neural spine and most of the

188 transverse processes are missing. The centrum is notably robust and amphi-platycoelous, with

189 the articular surfaces being oval in outline and slightly higher than wide. The anterior articular

190 surface has suffered from erosion, so that its exact size and morphology cannot be established,

191 but the posterior articular surface is only slightly concave and only slightly higher (c. $150 \mathrm{~mm}$ )

192 than wide (c. 140-145 mm as reconstructed; the right rim is eroded). In lateral view, the posterior

193 articular surface is notably offset ventrally in respect to the anterior surface (Fig. 4A). The length

194 of the centrum as preserved is c. $140 \mathrm{~mm}$, but approximately $10 \mathrm{~mm}$ might be missing anteriorly,

195 so that the centrum was approximately as high as long. In ventral view, the centrum is

196 moderately constricted to a minimal width of c. $90 \mathrm{~mm}$ between the articular ends. Ventrally, a

197 broad, but shallow ventral groove is present, which becomes more marked posteriorly between

198 the poorly developed chevron facets (Fig. 4C). The lateral sides of the centrum are strongly

199 convex dorsoventrally and offset from the ventral surface by the broadly rounded edges of the

200 ventral groove. On the dorsal part of the lateral side of the centrum, below the base of the neural

201 arch, a notable, large pleurocentral depression is present (Fig. 4A). This depression is deeper

202 posteriorly than anteriorly, with the anteroventral part of the depression forming a small

203 lateroposteroventrally facing platform that is offset from the deeper posterior part by a rounded,

204 but notable oblique step. 
205 The walls of the neural arch are massive, and the neural canal is large (c. $35 \mathrm{~mm}$ in diametre) and 206 round to slightly oval in outline. The base of the massive transverse process is placed entirely on 207 the neural arch and extends for approximately the anterior three-fourths of the centrum.

208 Posteriorly, the transverse process is supported ventrally by a stout, posterolaterally facing posterior centrodiapophyseal lamina, the ventral end of which does not reach the posterodorsal end of the centrum (Fig. 4B). Whereas the left lamina forms a sharp, posterolaterally facing

211 edge, the right lamina seems to be more rounded, although this might be due to erosion. An 212 anterocentrodiapophyseal lamina is only indicated by a slight depression on the anterior side of 213 the base of the transverse process. The transverse process was laterally and strongly posteriorly 214 directed, but has almost no dorsal inclination. Posteriorly, a large postzygocentrodiapophyseal

215 fossa is present between the posterior centrodiapophyseal lamina and the lamina extending 216 ventrally between the medial ends of the postzygapophyses and the neural canal (Fig. 4B); as the 217 postzygapophyses are missing and the median lamina is poorly preserved, it is unclear if a small 218 hyposphene might have been present, but at least a marked ventral expansion of this lamina was 219 certainly absent. A small, ridge-like lamina extending from the dorsal margin of the transverse 220 process towards the dorsomedial rim of the neural canal subdivides the

221 postzygocentrodiapophyeal fossa into a larger, conical ventral recess and a smaller, much

222 shallower dorsomedial depression (Fig. 4B). Anteriorly, a small depression is present on the roof 223 of the neural canal, being offset from the massive dorsal surface of the transverse process by a 224 small, transverse step (Fig. 4D). The base of the broken neural spine is transversely narrow and 225 extends over the entire length of the neural arch, showing the eroded bases of the slightly 226 anteriorly diverging spinoprezygapophyseal laminae anteriorly.

\section{Asturian theropod tracks}

229 Following the definition of Marty et al. (2017), according to which giant theropod tracks are those of a FL 230 longer than $50 \mathrm{~cm}$, seven Asturian tracks are described in the present study (see table 1 for 231 measurements). The footprints (all more than $53 \mathrm{~cm}$ long), reported from the Kimmeridgian Lastres

232 Formation, are preserved as natural sandstone casts and can be classified into two groups by morphology 233 (Piñuela Suárez, 2015).

234

235 Morphotype A is represented by four tracks (Argüero1, Oles and Tazones specimens and MUJA-1889;

236 Fig. 5), which, although slightly different in morphology, are robust and weakly mesaxonic. The FL/FW 
237 ratio is very low $(0.88-1.16)$. The digit impressions are broad and generally show claw marks. The

238 divarication angle (II^IV) lies between $36^{\circ}$ and $40^{\circ}$. In some of these tracks the digital pads are visible.

239 Based on the morphology, the Asturian footprints would form part of the Megalosauripus-Kayentapus-

240 group proposed by Piñuela Suárez (2015), The specimens of morphotype A are thought to represent more

241 graviportal theropods (Piñuela Suárez, 2015) than those of morphotype B.

242

243 Argüero specimen 1. (Fig. 5A). The poorly preserved track represents a positive hyporelief. It is $70 \mathrm{~cm}$ 244 in length and $62 \mathrm{~cm}$ in width; thus, the FL/FW ratio is very low (0.88), considerably lower than in the 245 other tracks of the morphotype. The digit impressions are broad and relatively short, the best preserved 246 being digits II and III. The claw marks are evident, well developed and medially turned. It is possible to 247 recognize two pads in digit II. Digit IV is not well preserved, but enough is present to measure the 248 divarication angle between digits II and IV, which is $36^{\circ}$. Even though the end of the digit IV is not 249 preserved, the print seems weakly mesaxonic.

250

251 Oles specimen. (Fig. 5B). The footprint represents a shallow positive epirelief. It is $82 \mathrm{~cm}$ in length and $25266 \mathrm{~cm}$ in width, so the FL/FW ratio is 1.24 . The digit impressions are broad, slight less so than in the 253 previous specimen (Argüero specimen 1), and relatively short. Claw marks are evident in the three digits, being long and broad in digit II and shorter and narrower in III and IV. The digital pads are subtly visible, at least in digits III and IV. The divarication angle between digits II and IV is $38^{\circ}$. The track is weakly mesaxonic.

257

Tazones specimen. (Fig. 5C). The print represents a positive hyporelief. It is $57 \mathrm{~cm}$ in length and more than $47 \mathrm{~cm}$ in width (the end of the digit IV is not preserved), so the FL/FW ratio is at least 1.21. The digit impressions are long and less broad than in the previous specimens. The claw marks, only preserved in digits II and III, are relatively large, especially in digit II. The digital pads are subtly visible in digits II and III. The divarication angle between digits II and IV is $38^{\circ}$. Despite that the end of digit IV is not preserved, the print seems weakly mesaxonic. This footprint might be the best preserved of the morphotype A.

MUJA-1889. (Fig. 5D). The track represents a positive hyporelief. It is $53 \mathrm{~cm}$ in length and $53 \mathrm{~cm}$ in width, so the FL/FW ratio is 1 . The digit impressions are broad and short. The print is preserved as a shallow undertrack cast (associated to the true track cast), which might explain the poor definition of the claw marks, the absence of digital pads and the relatively anterior position of the hypeces. The divarication angle between digits II and IV is apparently very high if taken from the undertrack (giving 
271 an incorrect value); using the true cast, the divarication angle (II^IV) is $40^{\circ}$. The print is also weakly

272 mesaxonic. A horizontal outward translation movement is seen in this track, mainly in the digits II and III.

273 The maximum depth for the track is $16 \mathrm{~cm}$ in the distal part of digit III. The specimen MUJA-1889 was

274 recovered close to the Tazones specimen, and the composition and the thickness of the sandstone beds are

275 similar in both, suggesting that they are derived from the same stratigraphic level. Keeping in mind that

276 MUJA-1889 represents a different preservation (true track and shallow undertrack casts are associated)

277 and is also affected by an oblique foot displacement, the morphology of this footprint does not reflect the

278 foot anatomy of the producer, and thus could have been made by the same trackmacker that produced the

279 Tazones specimen.

280

281 Morphotype B is represented by three footprints (MUJA-1263, MUJA-0213 and Argüero specimen 2;

282 Fig. 6), which are much longer than wide and show a strong mesaxony. Pad impressions are only

283 preserved in one specimen. The claw impressions vary from narrow and short to wide and long. The

284 morphology of these footprints does not fit in large or giant known theropod ichnogenera, but rather with

285 smaller ones characterized by a higher mesaxony. This set of tracks seems to represent more cursorial

286 theropods (Piñuela Suárez, 2015) than morphotype A.

287

288

MUJA-1263. (Fig. 6A). This true sandstone cast represents a positive hyporelief and is associated with a

289 shallow undertrack. The print is much longer $(62 \mathrm{~cm})$ than wide $(38 \mathrm{~cm})$, so the FL/FW ratio is high

290 (1.63). The digit impressions are relatively broad and long, and the claw marks are large. Even though

291 this specimen is interpreted as an undertrack, it is possible to recognize two pads in digit II and three in digit III. The divarication angle (II^IV) is very low $\left(15^{\circ}\right)$. Although the end of digit II is not well preserved, the print is clearly highly mesaxonic. The maximum depth of the track is $10 \mathrm{~cm}$ in the distal part of digit III.

MUJA-0213. (Fig. 6B). The track represents a positive hyporelief. The posterior part of the track is not well preserved, and although it is difficult to recognize the proximal margin, the footprint is much longer

297 (78 cm) than wide (at least $35 \mathrm{~cm}$, but digit IV is not complete). The impression of digit III is very long and digit II is relatively short, but both of them are broad, due to flattening processes sensu Lockley and Xing (2015). The claw marks are short and narrow. Only two subtly visible pads are preserved in digit II.

300 Digit IV is not complete, but enough to measure the divarication angle between digits II and IV, $34^{\circ}$. The 301 print is highly mesaxonic, even though the digit IV is not complete.

302 Argüero specimen 2. (Fig. 6C). The footprint (an epirelief) seems to be longer $(67 \mathrm{~cm}$ ) than wide

303 (detailed measurements cannot be taken, because digit IV is not preserved). The impressions of the digits 
304 are broad, and digit III is very long, whereas digit II is relatively short. The claw marks in both are long

305 and narrow and medially directed in digit III. Digital pads are not recognizable in the digits. The

306 interdigital angle between digits II and III is high $\left(36^{\circ}\right)$. The print seems to have been highly mesaxonic,

307 although digit IV is not preserved.

308

309

DISCUSSION

310

\section{Systematic affinities of MUJA-1913}

312 Despite the incomplete preservation of the caudal vertebra reported here, its systematic affinities

313 can be narrowed down to at least a higher taxonomic category, although not to generic or species

314 level. Large-bodied theropod dinosaurs reported from the Late Jurassic of Europe so far include

315 members of the Ceratosauridae (Antunes \& Mateus, 2003; Mateus et al., 2006; Malafaia et al.,

316 2015), Megalosauridae (Antunes \& Mateus, 2003; Mateus et al, 2006; Carrano et al., 2012;

317 Hendrickx \& Mateus, 2014; Malafaia et al., 2017a), Metriacanthosauridae (Huene, 1926;

318 Walker, 1964; Carrano et al., 2012), and Allosauroidea (Pérez-Moreno et al., 1999; Mateus et al.,

319 2006; Malafaia et al., 2007, 2008a, 2010). Thus, comparisons of MUJA-1913 will mainly be

320 with these clades.

321 Concerning the position of MUJA-1913 within the caudal vertebral column, this element can be

322 quite confidently identified as a second or third caudal vertebra. Arguments in favour of this are

323 the well-developed posterior centrodiapophyseal lamina, which is only present in the

324 anteriormost caudal vertebrae, but is usually already less pronounced by caudal vertebra four

325 (Madsen, 1976). On the other hand, the first caudal usually lacks chevron facets, but they are

326 present on the posterior end of the centrum in MUJA-1913.

327 As no vertebral material of Ceratosaurus (the only ceratosaurian genus identified from the

328 Jurassic of Europe so far) or any other ceratosaur has been described from the Jurassic of

329 Europe, comparisons can only be made with Ceratosaurus from the Morrison Formation of the

330 western US (Gilmore, 1920; Madsen \& Welles, 2000). Anterior caudal vertebrae of this taxon

331 differ from MUJA-1913 in the considerably higher than wide articular facets of the centrum

332 (Madsen \& Welles, 2000: pl. 7), the lack of a pronounced offset of the articular facets (Gilmore,

333 1920; Madsen \& Welles, 2000), presence of a considerably narrower, deeper and better defined

334 groove on the ventral side (Gilmore, 1920: pl. 22; Madsen, 1976: fig. 8B), the presence of a 
335 large, ventrally expanded hyposphene in the anterior caudals, and the relatively smaller and not 336 subdivided postzygocentrodiapophyseal fossa (Madsen \& Welles, 2000). The anterior caudal

337 vertebrae of Ceratosaurus have marked pleurocentral depressions on the dorsolateral side of the 338 centrum (see Gilmore, 1920: pl. 22), but these are larger and less well-defined than in MUJA-

339 1913. Concerning other ceratosaurian lineages, anterior caudal vertebrae of abelisaurs differ 340 markedly from MUJA-1913 in lacking noted pleurocentral depressions, having well-developed

341 hyposphenes in anterior caudals (with the exception of Majungasaurus; O'Connor, 2007), and 342 usually strongly dorso-latero-posteriorly directed transverse processes (see Méndez, 2014). A 343 referral of MUJA-1913 to Ceratosauria (Martínez et al., 2000; Canudo \& Ruiz-Omeñaca, 2003) 344 thus seems untenable.

345 The anterior caudal vertebrae of the metriacanthosaurids Metriacanthosaurus (OUMNH J

346 12144) and Sinraptor (IVPP 10600; Currie \& Zhao, 1993) and the allosaurid Allosaurus (e.g.

347 MOR 693; Madsen, 1976) have centra that are notably higher than wide, have less notably offset

348 anterior and posterior articular facets, narrow towards their ventral side and lack both a notable

349 pleurocentral depression on the lateral side of the centrum as well as the subdivision of the

350 postzygocentrodiapophyseal fossa. Furthermore, a well-developed, ventrally expanded

351 hyposphene is present in the anterior caudal vertebrae of metriacanthosaurids, and the ventral

352 groove, if present, is notably narrower in allosauroids.

353 In contrast, the anterior caudal vertebrae of the megalosaurine megalosaurids Megalosaurus and

354 Torvosaurus are very similar to MUJA-1913. Both of these taxa have very massive anterior

355 caudal vertebral centra with a broad, posteriorly deepening ventral groove and a pronounced

356 offset of the articular surfaces (NHMUK R 9672; BYU 13745; Britt, 1991; Benson, 2010), and

357 the presence of marked pleurocentral depressions on the lateral sides of the caudal centra was

358 found to be a megalosaurine synapomorphy by Rauhut et al. (2016). Furthermore, these taxa lack

359 expanded hyposphenes in the caudal vertebrae and a subdivision of the

360 postzygocentrodiapophyseal fossa into a larger ventrolateral and a smaller, very shallow

361 dorsomedial portion is also present in at least one vertebra of Megalosaurus (NHMUK R 9672),

362 and seems to be also present in Torvosaurus (BYU 13745, BYU 5086). A small depression on

363 the dorsal roof of the anterior part of the base of the transverse process, very similar to that in

364 MUJA-1913, is also present in the anteriormost preserved caudal vertebra of the megalosaurid

365 Wiehenvenator (Rauhut et al., 2016). Given these similarities, including the possibly apomorphic 
366 characters of marked pleurocentral depressions and a subdivided postzygocentrodiapophyseal

367 fossa, we refer MUJA-1913 to an indeterminate megalosaurine megalosaurid. Given that the

368 genus Torvosaurus has been identified from the Late Jurassic of the Iberian Peninsula (Antunes

369 \& Mateus, 2003; Hendrickx \& Mateus, 2014; Malafaia et al., 2017a), this vertebra might

370 represent this taxon, but a positive generic or specific identification of this incomplete element is

371 impossible.

372

373 Size of MUJA-1913

374 One striking feature of the vertebra from the Vega Formation is its enormous size. With a

375 posterior centrum height of $150 \mathrm{~mm}$, MUJA-1913 is larger than most anterior caudals for which

376 measurements can be found in the literature. In particular, anterior caudals of Torvosaurus

377 tanneri are about 25\% smaller (Britt, 1991), an anterior caudal of Spinosaurus aegyptiacus is c.

$37810 \%$ smaller (Stromer, 1915), and one of the largest theropod caudals from the Jurassic, for

379 which measurements were given, a possible carcharodontosaurid caudal from the Tendaguru

380 Formation (Rauhut, 2011), is also c. 25\% smaller than the specimen described here. Larger

381 caudal vertebrae are present in the gigantic Cretaceous carcharodontosaurids (e.g. Canale et al.,

382 2015) and Tyrannosaurus (Brochu, 2003), but might also be found in the largest allosauroid

383 predators of the Late Jurassic Morrison Formation of the western USA (Chure, 1995, 2000;

384 Williamson \& Chure, 1996), though no measurements are available in the literature for these

385 specimens. However this may be, Hendrickx \& Mateus (2014) argued that the holotype of

386 Torvosaurus guerneyi represented the largest theropod dinosaur yet recorded from Europe (see

387 also specimens described by Malafaia et al., 2017a). This specimen includes a partial anterior

388 caudal vertebra, the posterior articular surface of which is about $15 \%$ smaller than that of MUJA-

389 1913. Thus, given that the specimen from the Vega Formation probably belongs to a closely

390 related taxon, this specimen probably represents the largest theropod dinosaur recorded so far in

391 Europe, and represents an apex predator of more than $10 \mathrm{~m}$ in length.

392 It should be noted that Pharisat (1993) briefly reported large theropod caudal vertebrae from the

393 Oxfordian of Plaimbois-du-Miroi, Doubs, France (see also Allain \& Pereda-Suberbiola, 2003),

394 which, according to the measurements given, are of closely comparable size to MUJA-1913.

395 Although no detailed description of these elements has ever been published, several characters

396 indicate megalosaurid affinities for these elements: the general shape of the centra and neural 
397 arches, the presence of a marked pleurocentral depression in the slightly more posterior vertebra,

398 the almost circular outline of the posterior articular surface and the absence of a hyposphene in

399 the probably first caudal, and the subdivision of the postzygocentrodiapophyseal fossa into a

400 dorsomedial platform and a larger, conical ventrolateral depression (observations based on

401 unpublished photographs provided by Daniel Marty and Christian Meyer).

402 Other large Late Jurassic theropods from Europe have been reported on the basis of isolated teeth

403 (e.g. Lapparent, 1943; Buffetaut and Martin, 1993; Rauhut \& Kriwet, 1994; Canudo et al., 2006;

404 Ruiz-Omeñaca et al., 2009c; Cobos et al., 2014; Gerke \& Wings, 2016; Malafaia et al., 2017b),

405 and some of these specimens might represent animals that match MUJA-1913 in size (e.g.

406 specimen described by Cobos et al. [2014]; largest specimens described by Malafaia et al.

407 [2017b]). However, as relative tooth size varies widely in theropods, a direct size comparison is 408 impossible.

409

410 Ichnological evidence of giant theropods from the Kimmeridgian of Asturias

411 Regarding the giant theropod track record, Cobos et al. (2014) recently proposed that the Late

412 Jurassic-Early Cretaceous (Berriasian) theropod tracks can be divided in two main groups

413 (Ichno-group 1: Bueckeburgichnus-Hispanosauropus-Megalosauripus vs Ichno-group 2:

414 Iberosauripus), which can be distinguished by their narrowness / robustness, the proportion of

415 the length of digit III (mesaxony) or footprint proportions (FL/FW ratio). The authors proposed

416 that these two main groups might have been produced by members of Allosauridae and

417 Megalosauridae, respectively.

418 We partially agree with the two ichno-groups related to the narrowness/robustness and

419 strong/weak mesaxony proposed by Cobos et al. (2014) but less so with the ichnogenera

420 included within them (due to unresolved problems in ichnotaxonomy), and the identification of

421 some trackmakers (see below).

422 The validity of the Cretaceous German ichnogenus Bueckeburgichnus Kuhn, 1958, based on a

423 poorly preserved footprint, is questionable, because the irregular shape of the digits and the

424 relatively high total divarication angles suggesting extramorphological characters. Besides, the

425 ichnogenus was created on the basis of only one specimen. Thus, the outline of the track reflects

426 only partially the pedal morphology of the theropod. The tracks included in this ichnogenus were

427 considered to be Megalosauripus by Piñuela Suárez (2015; see also Hornung et al., 2012). 
428 The same applies to Hispanosauropus (Mensink and Mertmann, 1984; Lockley et al., 2007) from 429 the Kimmeridgian of Asturias, considered to be no valid ichnogenus by Piñuela Suárez (2015), 430 who included these Asturian tracks also in Megalosauripus. The poor preservation, which again 431 does not reflect faithfully the foot morphology of the trackmaker, the probability of destruction 432 and thus loss of the topotype located on an unstable sea cliff and the lack of a cast in any 433 museum are enough reasons to reject the validity of this ichnogenus (see also Lockley et al., 434 2007).

435 Regarding Megalosauripus, this is the typical Late Jurassic-Early Cretaceous ichnotaxon in 436 which many large theropod tracks have been included and that "has often been used as 437 wastebasket in 438 ichnotaxonomy “(see Razzolini et al., 2017; Belvedere et al., 2018 and references therein). 439 The problem concerns the comparison between some Megalosauripus tracks with the recently 440 defined large theropod ichnotaxa Iberosauripus (Cobos et al.,2014) or Jurabrontes (Marty et al., 441 2017).

442 On one hand, both shallow and deep undertracks belonging to large theropods, very frequent in 443 Asturias and usually preserved as casts, are normally wider than the casts of the true tracks 444 (Piñuela Suárez, 2015). This gives rise to footprints with relatively broader digit impressions, 445 similar to Megalosauripus uzbekistanicus (type specimen of Megalosauripus), M. teutonicus, 446 Iberosauripus or Jurabrontes (Lockley et al., 2000; see also Lockley et al., 1996; Diedrich, 447 2011; Cobos et al., 2014; Marty et al., 2018).

448 On the other hand, tracks produced in carbonate sediments are often not well preserved. They 449 sometimes tend, as in the undertracks, to be wider than the foot of the trackmaker and also show 450 broader digit impressions. Moreover, according to Razzolini et al. (2017) the material of 451 Iberosauripus grandis is rather poorly preserved. As stated correctly by Dalla Vecchia (2008: 452 99) "the footprint morphology is highly influenced by the properties of the substrate, mainly in 453 carbonate sedimentary settings" (see also Dalla Vecchia and Tarlao, 2000; Belvedere et al., 454 2008; Fanti et al., 2013). Thus, the substrate might have played a role when comparing large to 455 giant theropod tracks, giving relatively similar footprint morphologies. Although some 456 comparisons have recently been offered by Marty et al. (2017) and Razzolini et al. (2017), a 457 detailed revision of the ichnogenus Megalosauripus, including the three different ichnospecies 458 (M. uzbekistanicus, M. teutonicus, and M. transjuranicus), and an evaluation of the possible 
459 impact of locomotion and substrate in the production and distinction of large to giant theropod 460 tracks, such as Iberosauripus and Jurabrontes (Marty et al., 2017) are necessary to clarify the 461 ichnotaxonomic status of the Asturian tracks. In this respect, it is noteworthy that some of the 462 Asturian tracks (Argüero specimen 1, Oles specimen) of morphotype A described here generally 463 resemble Jurabrontes, as described by Marty et al. (2017). Nonetheless, they are also similar to 464 M. uzbekistanicus and M. teutonicus (Lockley et al., 1996, 2000), to some Late Jurassic tracks 465 assigned to Megalosauripus isp. (Diedrich, 2011; Lallensack et al., 2015; Mazin et al., 2016; 466 2017) and to Iberosauripus (Cobos et al., 2014). Some specimens of morphotype B resemble 467 tracks also assigned to Megalosauripus, but to the recently defined ichnospecies $M$.

468 transjuranicus (Razzolini et al., 2017), characterized by a higher mesaxony and its gracility in 469 comparison with the other aforementioned tracks, although this ichnospecies never reached the 470 size of the Asturian specimens.

471 Following the previous considerations, and given the poor preservation and the 472 ichnotaxonomical problems with the large to giant theropod tracks, we tentatively consider the 473 Asturian morphotype A as Megalosauripus-like, while the Asturian morphotype B cannot be 474 classified within any known ichnotaxa. The notably divergent morphology of the tracks included 475 in morphotypes A and B indicates that at least two taxa of giant theropod were present in the 476 Kimmerdigian of Asturias, as it seems very unlikely that the marked difference in mesaxony 477 between these morphotypes can be attributed to differences in preservation. In general terms, the 478 two morphotypes conform to the distinction proposed by Cobos et al. (2014) in that morphotype 479 A represents a very robust animal, whereas morphotype B seems to stem from a more gracile 480 theropods. The presence of two large theropods, one gracile and one robust, has already been 481 described in other Late Jurassic areas, such as the Jura Carbonate platform (Jurabrontes 482 curtedulensis and Megalosauripus transjuranicus, Razzolini et al., 2017; Marty et al., 2017) or 483 the Iouaridène Formation in Morocco (Megalosauripus and unnamed giant theropod tracks, 484 Boutakiout et al., 2009; Belvedere et al., 2010).

485 With up to $82 \mathrm{~cm}$, the Asturian specimens show footprint lengths that fall within the range of the 486 largest tracks in the world (Boutakiout et al., 2009; Piñuela Suárez, 2015; Marty et al. 2017).

487 Some of these large predators from the Late Jurassic of Asturias apparently had cursorial 488 adaptations, as deduced from the morphological study of their footprints (morphotype B), which 489 show strong mesaxony (sensu Lockley, 2009); their claw impressions, when preserved, are long 
490 and very narrow. These dinosaurs were as large as, but more agile than trackmakers of

491 Morphotype A tracks. The largest theropod trackmakers from the Jurassic of Asturias were thus

492 similar in size to Tyrannosaurus rex, based on known footprints of that taxon (e.g. Lockley \&

493 Hunt, 1994; Manning et al., 2008; McCrea et al., 2014) and foot skeletons (e.g. Brochu, 2003).

495 Late Jurassic apex predators in Europe

496 Apart from the ichnotaxonomic questions discussed above, the question remains which theropod

497 groups are represented by these giant tracks. As noted above, Cobos et al. (2014) suggested a

498 division of theropod tracks into two larger categories of robust and gracile prints (regardless of

499 the exact identification to ichnogenus or ichnospecies level), which they considered to represent

500 megalosaurids and allosaurids, respectively. The main argument for this identification was the

501 relative robustness or slenderness of the tracks: as the only well-known Late Jurassic

502 megalosaurid, Torvosaurus, is a very robust animal (Britt, 1991; Hendrickx \& Mateus, 2014;

503 Malafaia et al., 2017a), whereas the best known allosaurid, Allosaurus, is much more gracile

504 (e.g. Gilmore, 1920). Consequently, Cobos et al. (2014: 37-38) argued that the more robust

505 tracks were probably made by megalosaurids, whereas the more slender tracks correspond to

506 allosaurids.

507 However, this suggestion is somewhat simplistic and problematic for several reasons. The first

508 and obvious problem (also noted by Cobos et al., 2014) is that no complete pes is known in any

509 large ceratosaurian or Jurassic non-coelurosaurian tetanuran, with the exception of Allosaurus

510 (Madsen, 1976) and a specimen from the Lusitanian Basin that was originally also referred to

511 Allosaurus (Malafaia et al., 2008a), but might represent a carcharodontosaur (Malafaia et al.,

512 2017c). Even in the very complete holotype specimen of the metriacanthosaurid Sinraptor dongi,

513 several pedal phalanges are missing (Currie \& Zhao, 1993), and at the most isolated phalanges

514 are known for megalosaurids (Sereno et al., 1994; Allain \& Chure, 2002; Sadleir et al., 2008).

515 Thus, a synapomorphy-based correlation (sensu Carrano and Wilson, 2001) between pedal

516 morphology and trackways in large basal tetanurans is currently impossible. However, known

517 complete pedes of Allosaurus (e.g. Gilmore, 1920; Evers, 2014) do not seem to show the

518 extreme differences in digit III as opposed to digits II and IV that would lead to the mesaxony

519 seen in one of the largest footprints ascribed to morphotype B described here (MUJA-0213).

520 This extreme mesaxony is a strange situation in large theropod tracks as generally they tend to 
521 show lower mesaxony values than smaller theropod tracks (e.g.: Grallator-Eubrontes plexus;

522 Lockley, 2009).

523 A second problem in the identification proposed by Cobos et al. (2014) is that it neither takes the

524 systematic nor the morphological variation of known Jurassic averostrans that reach large to

525 giant sizes into account. First, allosaurids are not the only large allosauroids known from Europe,

526 with the English metriacanthosaurid Metriacanthosaurus representing an animal of similar or

527 even greater size than known specimens of Allosaurus from Europe (Huene, 1926; Walker,

528 1964; Pérez-Moreno et al., 1999; Mateus et al., 2006; Malafaia et al., 2010). However, the better

529 known metriacanthosaurids from China are similar in proportions and robustness to Allosaurus

530 (e.g. Dong et al., 1983; Currie \& Zhao, 1993; Gao, 1999), and the pes of Sinraptor does also not

531 seem to be significantly different from that of Allosaurus (see Madsen, 1976; Currie \& Zhao,

532 1993). Thus, the more slender tracks of Ichno-Group 1 of Cobos et al. (2014) might represent

533 metriacanthosaurids as well as allosaurids. On the other hand, the largest allosaurid known from

534 the Late Jurassic Morrison Formation of North America, Saurophaganax, is a more robustly

535 built animal (Chure, 1995, 2000), whereas afrovenatorine megalosaurids, such as Afrovenator

536 (Sereno et al., 1994) and Eustreptospondylus (Sadleir et al., 2008) are rather gracile animals.

537 Although Eustreptospondylus from the Callovian-Oxfordian boundary of England represents the

538 youngest afrovenatorine currently known from Europe (and, possibly globally, depending on the

539 uncertain age of Afrovenator), the Late Jurassic European theropod fossil record is insufficient to

540 completely rule out their survival into later stages, and at least caution is advisable in identifying

541 tracks as allosauroid on the basis of their slenderness only.

542 Finally, the basal ceratosaur Ceratosaurus, known from the Late Jurassic of Portugal (Antunes \&

543 Mateus, 2003; Mateus et al., 2006; Malafaia et al., 2015) is a rather large animal as well

544 (Gilmore, 1920; Madsen \& Welles, 2000). Although the holotype of Ceratosaurus nasicornis

545 has been estimated with a total length of slightly more than $5 \mathrm{~m}$ (Gilmore, 1920), the type of $C$.

546 dentisulcatus is about 22\% larger (Madsen \& Welles, 2000), and other specimens (e.g. BYU

547 881) reach sizes comparable to that of large specimens of Allosaurus. As Ceratosaurus is also a

548 rather gracile animal, exceptionally large individuals of this or a closely related taxon could also

549 have made the more gracile tracks.

550 Concerning megalosaurine megalosaurids, no pedal elements other than metatarsals have been

551 described for any of the included genera Duriavenator, Megalosaurus, Wiehenvenator, and 
552 Torvosaurus (Galton \& Jensen, 1979; Britt, 1991; Benson, 2008b, 2010; Hanson \& Makovicky, 553 2014; Hendrickx \& Mateus, 2014; Rauhut et al., 2016; Malafaia et al., 2017a). However, at least

554 Megalosaurus, Wiehenvenator and Torvosaurus are notable for their extreme robustness, and

555 Williamson \& Chure (1996: 78) cite a personal communication by James Madsen, according to

556 which the pedal phalanges of Torvosaurus are notably short and wide. These observations are

557 thus in agreement with the suggestion by Cobos et al. (2014) that the very robust tracks with a

558 low mesaxony might represent (megalosaurine) megalosaurids. Nevertheless, we agree with

559 Marty et al. (2017) that caution is advisable in assigning giant theropod tracks from the Jurassic

560 to any clade unless better data on pedal morphology in basal tetanurans becomes available.

561 Regardless of the exact identification of the trackmaker, European sites have yielded some of the

562 largest known Jurassic theropod tracks, such as the trackways described from the Middle Jurassic

563 of Oxforshire, UK, (Day et al., 2004) and Vale de Meios, Portugal, (Razzolini et al., 2016),

564 which were made by giant theropods, tentatively attributed to Megalosaurus and to the

565 Megalosauridae, respectively. Recently, Marty et al., (2017) described new giant theropod tracks

566 (Jurabrontes curtedulensis) from the Kimmeridgian of NW Switzerland. This new ichnotaxon is

567 characterized by tracks that are slightly longer than wide and show weak mesaxony, and, as the

568 authors suggested, can be included within the main features of the Ichno-Group 2 of Cobos et al.,

569 (2014). These authors emphasized that some of the Jurabrontes tracks are among the largest

570 theropod tracks worldwide. However, the Kimmeridgian of Asturias is the only Jurassic

571 European site that has yielded tracks of two giant theropods (gracile and robust) so far, indicating

572 that two different clades of giant theropods were present here.

573 Concerning osteological remains, the identification of MUJA-1913 as a megalosaurid adds to the

574 already diverse European fossil record of the clade. As discussed by Benson (2010), Carrano et

575 al. (2012) and Rauhut et al. (2016), megalosaurids were taxonomically diverse and widespread in

576 the Middle Jurassic of Europe. However, whereas megalosaurids are rare in the Kimmeridgian-

577 Tithonian Morrison Formation of the western US (Foster, 2003; Rauhut et al., 2016), and

578 unknown from the Late Jurassic of Asia, they seem to be abundant and wide-spread in the Late

579 Jurassic of Europe. From the Lusitanian Basin, the large megalosaurid Torvosaurus guerneyi and

580 several other megalosaurid postcranial specimens, numerous teeth, as well as eggs and embryos

581 were described (Antunes \& Mateus, 2003; Mateus et al., 2006; Malafaia et al., 2008b, 2017a, b;

582 Araújo et al., 2013; Hendrickx \& Mateus, 2014). From the Late Jurassic Villar del Arzobispo 
583 Formation of the Iberian Range, Gascó et al. (2012) and Cobos et al. (2014) referred isolated

584 teeth to the Megalosauridae, including the largest tooth specimen found in these rocks (Cobos et 585 al., 2014). Likewise, Gerke \& Wings (2016) identified the largest theropod teeth in their sample 586 from the Kimmeridgian of northern Germany as probable megalosaurids. Furthermore, the early 587 juvenile megalosaurid Sciurumimus was found in the Kimmeridgian Torleite Formation of 588 Bavaria (Rauhut et al., 2012; the layers were referred to the Rögling Formation in that paper, but 589 recent lithostratigraphic revisions place the Kimmeridgian beds at Painten in the Torleite 590 Formation; Niebuhr \& Pürner, 2014). Apart from the fragmentary skeleton of the large-bodied 591 metriacanthosaurid Metriacanthosaurus from the Oxfordian Oxford Clay (Huene, 1926; Walker, 592 1964), all identifiable large theropod remains from the Late Jurassic of England seem to 593 represent megalosaurids as well, including remains of a large maxilla and a very robust tibia 594 from the Kimmeridge Clay (Benson \& Barrett, 2009; Carrano et al., 2012). As noted above, the 595 largest Jurassic theropod remains found in France (Pharisat, 1993) also seem to represent a 596 megalosaurid. The specimen described here from the Kimmeridgian of Asturias fits well in this 597 general panorama.

598 Thus, megalosaurid theropods seem to have represented the largest predators on all of the Late 599 Jurassic European landmasses that we have fossil evidence for, together with allosaurids in the 600 western parts of Europe and metriacanthosaurids in the eastern areas. As these parts of Europe 601 were an assemblage of medium-sized islands and most of the sediments that have yielded 602 theropod remains are either nearshore terrestrial or even marine beds, this seems to support the 603 suggestion of Rauhut et al. (2016) that megalosaurids might have preferred nearshore 604 environments, and that the apparent faunal change from megalosaurid-dominated to allosauroid605 dominated faunas from the Middle to the Late Jurassic might rather reflect regional and 606 environmental biases in the fossil record of Jurassic theropods.

607 Given the abundance and wide distribution of megalosaurids in the Late Jurassic of Europe, the 608 question arises if different lineages of megalosaurids populated the different landmasses, 609 possibly evolving in isolation from their Middle Jurassic predecessors, or if an interchange of 610 megalosaurid taxa between the different islands might have been possible. The presence of 611 abundant theropod tracks, the largest of which are often related to megalosaurids, in shallow 612 marine or carbonate platform environments (e.g. Marty et al. 2017) might indicate that short time 613 sea level changes may have allowed some faunal interchange between otherwise separate 
614 landmasses during the Late Jurassic (Meyer, 2012). Indeed, Marty et al., (2017) suggested that

615 the Jura carbonate platform could have represented a "faunal exchange corridor" of the dinosaur

616 faunas between the southern and the northern landmasses.

617 Similarly large theropod tracks have also been reported from the Late Jurassic of northern Africa

618 (Boutakiout et al., 2009). Belvedere (2008; see also Belvedere et al., 2010; Marty et al., 2010)

619 noted great similarities between ichnofaunas from the Late Jurassic of Morocco and the Jura

620 Mountains. The possibility of faunal interchange between Europe and North Africa through an

621 Iberian corridor during the Early Cretaceous was discussed by Canudo et al. (2009), who

622 concluded that such an interchange was improbable before the Barremian-Aptian. In the Late

623 Jurassic, at least along the south-south-eastern margin of Iberia, this land mass was separated

624 from Africa by oceanic floor (Olóriz, 2002), and sediments from the northern shore of this

625 oceanic basin in the Betic Cordillera indicate pelagic conditions (Olóriz et al., 2002), indicating

626 that there was a rather wide separation of Iberia from northern Africa in this region. Even though

627 the Ligurian sea floor spreading most probably did not extend into the region of the opening

628 central Atlantic (Ford \& Golonka, 2003), continental rifting extended between the Ligurian

629 ocean and the area around Gibraltar, forming a considerably thinned continental lithosphere

630 consisting of pull-apart basins that make up the Alboran Basin, which, with a width of at least

631 100-200 km (and possible twice as much), separated northern Africa from Iberia during the Late

632 Jurassic (Capitanio \& Goes, 2006), being flooded by epicontinental seas. This region

633 furthermore experienced significant transformational tectonics (Capitanio \& Goes, 2006).

634 Although short time emergence of parts of this area due to eustatic sea level changes might not

635 be completely impossible, the complete formation of a land bridge between Iberia and northern

636 Africa in the Late Jurassic seems unlikely. Although at least sporadic intervals of faunal

637 interchange cannot be completely ruled out, the possibility of a dinosaur interchange between

638 Europe and northern Africa during the Late Jurassic seems rather improbable due to the

639 continuous seaway (the "Hispanic Corridor") connecting the Tethys sea with the Panthalassan

640 ocean, as revealed by known palaeogeographic reconstructions (Ziegler, 1988; Dercourt et al.,

641 2000; Ford \& Golonka, 2003; Vrielynck \& Bouysse, 2003). In addition, the global sea-level

642 reached its Jurassic maximum during the Late Kimmeridgian-Early Tithonian times, although

643 short-time fluctuations in sea level are also notable during this interval (Haq, 2018). 
644 Unfortunately, there is no osteological record of theropods from the Late Jurassic of northern

645 Africa, so nothing can be said about possible faunal similarities and differences between this

646 region and Europe. Traditionally, scientists have pointed out the allegedly great similarity of the

647 Late Jurassic fauna of the east African Tendaguru Formation to that of the Morrison Formation

648 (e.g. Galton, 1977, 1982) and the Lusitanian Basin (e.g. Mateus, 2006), but recent research has

649 rather emphasized the differences between this Gondwanan fauna from its contemporaneous

650 Laurasian counterparts (e.g. Remes, 2006; Taylor, 2009; Hübner \& Rauhut, 2010; Rauhut,

651 2011). Interestingly, though, the Tendaguru theropod fauna seems to also include at least three

652 large to giant theropod taxa, including a possible abelisaurid, a possible megalosaur, and a

653 probably carcharodontosaurian allosauroid (Rauhut, 2011). Thus, the same general lineages are

654 present in the fauna of apex predators in eastern Africa and Europe, although the exact clades

655 represented might be different (though note that Malafaia et al. [2017c] recently identified the

656 first possible carcharodontosaurian from the Lusitanian Basin). Whether this is due to shared

657 heritage from Pangean times, or if some faunal interchange might, at least sporadically, have

658 been possible can only be answered in the light of future discoveries from northern Africa.

659 On the other hand, the comparison between theropod tracks of both continental blocks might not

660 be too significant, since, as pointed out by Farlow (2001: 417-421): “...pedal phalangeal

661 skeletons of large ceratosaurs, allosaurs and tyrannosaurs are indistinguishable. That being the

662 case, it is probably impossible to correlate large-theropod footprints with the clades of their

663 makers on the basis of print shape alone. ...using large-theropod ichnotaxa to make

664 intercontinental correlations (...) is a procedure that should be done with considerable caution.

665 Footprints that on morphological grounds can be placed in the same ichnotaxon might have been

666 made by large theropods that were not closely related".

667 However, the different features seen in the large theropod tracks from Asturias, the Jura

668 carbonate platform and Morocco in the Late Jurassic seem to at least partially contradict Farlow

669 (2001). The presence of two different large to giant theropods in the Late Jurassic is supported

670 by the ichnological evidence in several places, in which clearly distinguishable robust and gracile

671 morphotypes are found, suggesting that, although different genera/species might have inhabited

672 Europe and North Africa, two groups, one gracile and one robust, were present.

673

674

CONCLUSIONS 
676 The presence of very large theropods in the Asturian Basin (Northern Spain) during the Upper

677 Jurassic (Kimmeridgian) is confirmed by both the footprints and skeletal remains. Whereas the

678 only skeletal remain of a giant theropod from the Vega Formation represents a megalosaurine

679 megalosaurid, the track record indicates at least two taxa of giant theropods in the slightly

680 younger Lastres Formation. Both osteological and ichnological evidence indicates that very large

681 to giant theropod dinosaurs were widespread in Europe in the Late Jurassic, and the largest

682 representatives seem to have been close to the maximum body size recorded for theropods.

683 Given that Europe represented an assemblage of larger and smaller islands at that time, this is

684 surprising, as maximum body size is usually correlated with available land mass in vertebrates

685 (Marquet \& Taper, 1998; Burness et al., 2001), and island dwarfing has been reported in

686 dinosaurs (e.g. Sander et al., 2006; Stein et al., 2010). A possible solution to this apparent

687 contradiction might be that short time sea level changes allowed faunal interchange between the

688 different islands that constituted Europe repeatedly during the Late Jurassic. Dinosaur tracks

689 preserved in shallow marine carbonate platform environments might be direct evidence for this

690 (Marty et al., 2017). The preference of nearshore environments in megalosaurids, possibly in

691 search for suitable food (Razzolini et al., 2016) might furthermore explain the wide distribution

692 of this group in the European archipelago.

693

694 ACKNOWLEDGEMENTS

695 We thank Daniel Marty and Christian Meyer for providing photographs of the theropod

696 vertebrae from Plaimbois-du-Miroi and help with literature and Adriana López-Arbarello for

697 discussions. Matteo Belvedere and Elisabete Malafaia improved the work with critical

698 comments.

699

700

REFERENCES

701

702

Allain R, and Chure DJ. 2002. Poekilopleuron bucklandii, the theropod dinosaur from the

703 Middle Jurassic (Bathonian) of Normandy. Palaeontology 45:1107-1121.

704

Allain R, and Pereda Suberbiola X. 2003. Dinosaurs of France. Comptes Rendus Palevol 2:27705 44. 
706 Antunes MT, and Mateus O. 2003. Dinosaurs of Portugal. Comptes Rendus Palevol 2:77-95.

707 Araújo R, Castanhinha R, Martins R, Mateus O, Hendrickx C, Beckmann F, Schell N, and Alves

708 L. 2013. Filling the gaps of dinosaur eggshell phylogeny: Late Jurassic Theropod clutch

709 with embryos from Portugal. Scientific Reports 3:1924.

710

Arenas C, Piñuela L, and García-Ramos JC. 2015. Climatic and tectonic controls on carbonate

711 deposition in syn-rift siliciclastic fluvial systems: A case of microbialites and associated

712 facies in the Late Jurassic. Sedimentology 62:1149-1183.

713

Aurell M, Badenas B, Gasca J, Canudo J, Liesa C, Soria A, Moreno-Azanza M, and Najes L. 2016. Stratigraphy and evolution of the Galve sub-basin (Spain) in the middle Tithonianearly Barremian: Implications for the setting and age of some dinosaur fossil sites. Cretaceous Research 65:138-162.

Avanzini M, García-Ramos JC, Lires J, Menegon M, Piñuela L, and Fernández LA. 2005. Turtle tracks from the Late Jurassic of Asturias, Spain. Acta Paleontologica Polonica 50:743755.

Avanzini M, Piñuela L, and García-Ramos JC. 2008. Paleopathologies deduced from a theropod trackway. Upper Jurassic of Asturias (N Spain). Oryctos 8:71-75.

Avanzini M, Pinuela L, and García-Ramos J. 2012. Late Jurassic footprints reveal walking kinematics of theropod dinosaurs. Lethaia 45:238-252.

Belvedere M. 2008. Ichnological researches on the Upper Jurassic dinosaur tracks in the Iouaridène area (Demnat, central High-Atlas, Morocco) PhD-thesis. Università degli Studi di Padova.

Belvedere M, Avanzini M, Mietto P, and Rigo M. 2008. Norian dinosaur footprints from the "Strada delle Gallerie" (Monte Pasubio, NE Italy). Studi Trentini di Scienze Naturali, Acta Geologica 83:267-275. 
736 Belvedere M, Mietto P, and Ishigaki S. 2010. A Late Jurassic diverse ichnocoenosis from the

737

738

739

740

741

742

743

744

745

746

747

748

749

750

751

752

753

754

755

756

757

758

759

760

761

762

763

764

765

766 siliciclastic Iouaridene Formation (Central High Atlas, Morocco). Geological Quarterly 54:367-380.

Belvedere M, Bennett MR, Marty D, Budka,M, Reynolds SC, and Bakirov R. 2018. Stat-tracks and mediotypes: powerful tools for modern ichnology based on 3D models. PeerJ 6, e4247.

Benson R, and Barrett P. 2009. Dinosaurs of Dorset: Part I, the carnivorous dinosaurs (Saurischia, Theropoda). Proceedings of the Dorset Natural History and Archaeological Society 130:133-147.

Benson RBJ. 2008a. New information on Stokesosaurus, a tyrannosauroid (Dinosauria: Theropoda) from North America and the United Kingdom. Journal of Vertebrate Paleontology 28:732-750.

Benson RBJ. 2008b. A redescription of 'Megalosaurus' hesperis (Dinosauria, Theropoda) from the Inferior Oolite (Bajocian, Middle Jurassic) of Dorset, United Kingdom. Zootaxa 1931:57-67.

Benson RBJ. 2010. A description of Megalosaurus bucklandii (Dinosauria: Theropoda) from the Bathonian of the UK and the relationships of Middle Jurassic theropods. Zoological Journal of the Linnean Society 158:882-935.

Bertling M, Braddy SJ, Bromley RG, Demathieu GR, Genise J, Mikuláš R, Nielsen JK, Nielsen KSS, Rindsberg AK, Schlirf M, and Uchman A. 2006. Names for trace fossils: a uniform approach. Lethaia 39:265-286.

Boutakiout M, Hadri M, Nouri J, Díaz-Martínez I, and Pérez-Lorente F. 2009. Rastrilladas de icnitas terópodas gigantes del Jurásico Superior (Sinclinal de Iouaridène, Marruecos). Revista Española de Paleontología 24:31-46.

Britt BB. 1991. Theropods of Dry Mesa Quarry (Morrison Formation, Late Jurassic), Colorado, with emphasis on the osteology of Torvosaurus tanneri. BYU Geology Studies 37:1-72.

Brochu CA. 2003. Osteology of Tyrannosaurus rex: insights from a nearly complete skeleton and high-resolution computed tomographic analysis of the skull. Society of Vertebrate Paleontology, Memoir 7:1-138.

Buffetaut E, and Martin M. 1993. Late Jurassic dinosaurs from the Boulonnais (northern France): a review. Revue de Palebiologie, Volume spécial 7:17-28. 
767 Burness GP, Diamond J, and Flannery T. 2001. Dinosaurs, dragons, and dwarfs: the evolution of

768

769

770

771

772

773

774

775

776

777

778

779

780

781

782

783

784

785

786

787

788

789

790

791

792

793

794

795

796 maximal body size. Proceedings of the National Academy of Sciences 98:14518-14523.

Campos-Soto S, Cobos A, Caus E, Benito MI, Fernández-Labrador L, Suarez-Gonzalez P, Quijada IE, Mas R, Royo-Torres R, and Alcalá L. 2017. Jurassic Coastal Park: A great diversity of palaeoenvironments for the dinosaurs of the Villar del Arzobispo Formation (Teruel, eastern Spain). Palaeogeography, Palaeoclimatology, Palaeoecology 485: 154177.

Canale J, Novas F, and Pol D. 2015. Osteology and phylogenetic relationships of Tyrannotitan chubutensis Novas, de Valais, Vickers-Rich and Rich, 2005 (Theropoda: Carcharodontosauridae) from the Lower Cretaceous of Patagonia, Argentina. Historical Biology 27:1-32.

Canudo JI, Aurell M, Barco JL, Cuenca-Bescós G, and Ruiz-Omeñaca JI. 2005. Los dinosaurios de la Formación Villar del Arzobispo (Titónico medio - Berriasiense inferior) en Galve (Teruel). Geogaceta 38:39-42.

Canudo JI, Barco JL, Pereda Suberbiola X, Ruiz-Omeñaca JI, Salgado L, Torcida F, and Gasulla JM. 2009. What Iberian dinosaurs reveal about the bridge said to exist between Gondwana and Laurasia in the Early Cretaceous. Bulletin de la Societé géologique de France 180:5-11.

Canudo J, Ruiz-Omenaca J, Aurell M, Barco J, and Cuenca-Bescos G. 2006. A megatheropod tooth from the late Tithonian - middle Berriasian (Jurassic-Cretaceous transition) of Galve (Aragon, NE Spain). Neues Jahrbuch für Geologie und Paläontologie, Abhandlungen 239:77-99.

Canudo JI, and Ruiz-Omeñaca JI. 2003. Los restos directos de dinosaurios terópodos (excluyendo Aves) en España. In: Pérez-Lorente F, ed. Dinosaurios y otros Reptiles Mesozoicos en España. Logroño: Instituto de Estudios Riojanos, 347-374.

Canudo JI, Ruiz-Omeñaca JI, Piñuela L, and García-Ramos JC. 2010. Descripción de un dentario de cf. Turiasaurus (Sauropoda) del Kimmeridgiense de Asturias (España). In: RuizOmeñaca JI, Piñuela L, and García-Ramos JC, eds. Comunicaciones del V Congreso del Jurásico de España Museo del Jurásico de Asturias (MUJA), Colunga, 8-11 de septiembre de 2010. Colunga: Museo del Jurásico de Asturias, 164-169. 
797 Capitanio F, and Goes S. 2006. Mesozoic spreading kinematics: consequences for Cenozoic

798

799

800

801

802

803

804

805

806

807

808

809

810

811

812

813

814

815

816

817

818

819

820

821

822

823

824

825

Central and Western Mediterranean subduction. Geophysical Journal International 165:804-816.

Carrano MT, Benson RBJ, and Sampson SD. 2012. The phylogeny of Tetanurae (Dinosauria: Theropoda). Journal of Systematic Palaeontology 10:211-300.

Carrano MT, and Wilson JA. 2001. Taxon distributions and the tetrapod track record. Paleobiology 27:564-582.

Castanera D, Piñuela L, and García-Ramos JC. 2016. Grallator theropod tracks from the Late Jurassic of Asturias (Spain): ichnotaxonomic implications. Spanish Journal of Palaeontology 31:283-296.

Chure DJ. 1995. A reassessment of the gigantic theropod Saurophagus maximus from the Morrison Formation (Upper Jurassic) of Oklahoma, USA. In: Sun A, and Wang Y, eds. Sixth Symposium on Mesozoic Terrestrial Ecosystems and Biota, Short Papers. Beijing: China Ocean Press, 103-106.

Chure DJ. 2000. A new species of Allosaurus from the Morrison Formation of Dinosaur National Monument (UT-CO) and a revision of the theropod family Allosauridae. Unpublished PhD thesis. New York: Columbia University.

Cobos A, Lockley M, Gascó F, Royo-Torres R, and Alcala L. 2014. Megatheropods as apex predators in the typically Jurassic ecosystems of the Villar del Arzobispo Formation (Iberian Range, Spain). Palaeogeography Palaeoclimatology Palaeoecology 399:31-41.

Conti MA, Morsilli M, Nicosia U, Sacchi E, Savino V,Wagensommer A, Di Maggio L, and Gianolla P. 2005. Jurassic dinosaur footprints from southern Italy: footprints as indicators of constraints in paleogeographic interpretation. Palaios 20(6):534-550 DOI 10.2110/palo.2003.p03-99.

Cosentino D, Cipollari P, Marsili P, and Scrocca D. 2010. Geology of the central Apennines: a regional review. Journal of the Virtual Explorer 36:11.

Currie PJ, and Zhao X-J. 1993. A new carnosaur (Dinosauria, Theropoda) from the Jurassic of Xinjiang, People's Republic of China. Canadian Journal of Earth Sciences 30:20372081. 
826 Dalla Vecchia FM. 2008. The impact of dinosaur palaeoichnology in palaeoenvironmental and

827

828

829

830

831

832

833

834

835

836

837

838

839

840

841

842

843

844

845

846

847

848

849

850

851

852

853

854 palaeogeographic reconstructions: the case of Periadriatic carbonate platforms. Oryctos 8:89-106.

Dalla Vecchia FM, and Tarlao A. 2000. New dinosaur tracks sites in the Albian (Early Cretaceous) of the Istrian Peninsula (Croatia). Parte II, Paleontology. Memorie di Scienze Geologische 52:227-292.

Day JJ, Norman DB, Gale AS, Upchurch P, and Powell HP. 2004. A Middle Jurassic dinosaur trackway site from Oxfordshire, UK. Palaeontology 47:319-348.

Dercourt J, Gaetani M, Vrielynck B, Barrier E, Biju-Duval B, Brunet M, Cadet JP, Crasquin S, and Săndulescu N (Eds). 2000. Atlas peri-Tethys, palaeogeographical maps. Paris: CCGM/CGMW.

Diedrich C. 2011. Upper Jurassic tidal flat megatracksites of Germany-coastal dinosaur migration highways between European islands, and a review of the dinosaur footprints. Palaeobiology and Palaeoenvironments 91:129-155.

Dong Z, Zhou S, and Zhang Y. 1983. [The dinosaurian remains from Sichuan Basin, China]. Palaeontologia Sinica 162:1-145. (in Chinese)

Escaso F, Ortega F, Dantas P, Malafaia E, Pimentel N, Pereda-Suberbiola X, Sanz J, Kullberg J, Kullberg M, and Barriga F. 2007. New evidence of shared dinosaur across Upper Jurassic Proto-North Atlantic: Stegosaurus from Portugal. Naturwissenschaften 94:367-374.

Evers SW. 2014. The postcranial osteology of a large specimen of Allosaurus "jimmadsoni" (Dinosauria: Theropoda) from the Late Jurassic of Wyoming, U.S.A. Unpublished M.Sc.thesis. Munich: Ludwig-Maximilians-University.

Fanti F, Contessi M, Nigarov A, and Esenov P. 2013. New data on two large dinosaur tracksites from the Upper Jurassic of Eastern Turkmenistan (Central Asia). Ichnos 20:54-71.

Farlow JO. 2001. Acrocanthosaurus and the maker of Comanchean large-theropod footprints. In: Tanke DH, and Carpenter K, eds. Mesozoic vertebrate life. Bloomington: Indiana University Press, 408-427.

Ford D, and Golonka J. 2003. Phanerozoic paleogeography, paleoenvironment and lithofacies maps of the circum-Atlantic margins. Marine and Petroleum Geology 20:249-285. 
855 Foster JR. 2003. Paleoecological analysis of the vertebrate fauna of the Morrison Formation

856

857

858

859

860

861

862

863

864

865

866

867

868

869

870

871

872

873

874

875

876

877

878

879

880

881

882

883

884

(Upper Jurassic), Rocky Mountain Region, USA. Bulletin of the New Mexico Museum of Natural History \& Science 23:1-95.

Foth C, and Rauhut O. 2017. Re-evaluation of the Haarlem Archaeopteryx and the radiation of maniraptoran theropod dinosaurs. BMC Evolutionary Biology 17:236.

Galton PM. 1977. The ornithopod dinosaur Dryosaurus and a Laurasia - Gondwanaland connection in the Upper Jurassic. Nature 268:230-232.

Galton PM. 1982. Elaphrosaurus, an ornithomimid dinosaur from the Upper Jurassic of North America and Africa. Paläontologische Zeitschrift 56:265-275.

Galton PM, and Jensen JA. 1979. A new large theropod dinosaur from the Upper Jurassic of Colorado. BYU Geology studies 26:1-12.

Gao Y. 1999. A complete carnosaur skeleton from Zigong, Sichuan - Yangchuanosaurus hepingensis. Chengdu: Sichuan Science and Technology Press.

García-Ramos JC, Aramburu C. and Piñuela L. 2010c. Las series fluviales del Jurásico Superior de Asturias (Formación Vega). In: García-Ramos JC ed. V Congreso del Jurásico de España. Guía de campo (excursión A). Las sucesiones margo-calcáreas marinas del Jurásico Inferior y las series fluviales del Jurásico Superior. Acantilados de playa de Vega (Ribadesella). Colunga: Museo del Jurásico de Asturias, 53-63.

García-Ramos JC, Piñuela L, and Aramburu C. 2010b. La Formación Tereñes en su localidad tipo. In: García-Ramos JC, and Aramburu C. eds. V Congreso del Jurásico de España. Guía de campo (excursión B). Las Sucesiones Litorales y Marinas Restringidas del Jurásico Superior. Acantilados de Tereñes (Ribadesella) y de la Playa de La Griega (Colunga). Colunga: Museo del Jurásico de Asturias, 15-40.

García-Ramos JC, Piñuela L, and Lires J. 2006. Atlas del Jurásico de Asturias. Oviedo: Ediciones Nobel.

García-Ramos JC, Piñuela L, and Rodríguez-Tovar FJ. 2011. Post-workshop field trip guide of the XI International Ichnofabric Workshop. Colunga: Museo del Jurásico de Asturias.

García-Ramos JC, Piñuela L, Uzqueda H, Poblet J, Bulnes M, Alonso JL, and Suárez-Vega LC. 2010a. Travertinos ricos en oncoides asociados a paleomanantiales y lagos efímeros próximos a fallas sinsedimentarias en el Jurásico Superior de Asturias. In: Ruiz-Omeñaca 
885

886

887 Gascó F, Cobos A, Royo-Torres R, Mampel L, and Alcalá L. 2012. Theropod teeth diversity

888

889

890

891

892

893

894

895

896

897

898

899

900

901

902

903

904

905

906

907

908

909

910

911

912

913

914

JI, Piñuela L, and García-Ramos JC, eds. Comunicaciones del V Congreso del Jurásico de España. Colunga: Museo del Jurásico de Asturias, 83-91.

from the Villar del Arzobispo Formation (Tithonian-Berriasian) at Riodeva (Teruel, Spain). Palaeobiology and Palaeoenvironments 92:273-285.

Gerke O, and Wings O. 2016. Multivariate and cladistic analyses of isolated teeth reveal sympatry of theropod dinosaurs in the Late Jurassic of Northern Germany. Plos One 11(7):e0158334.

Gierlinski G, and Niedźwiedzki G. 2002. Dinosaur footprints from the Upper Jurassic of Błaziny. Geological Quarterly 46:463-465.

Gierlinski G, Niedźwiedzki G, and Nowacki P. 2009. Small theropod and ornithopod footprints in the Late Jurassic of Poland. Acta Geologica Polonica 59:221-234.

Gilmore CW. 1920. Osteology of the carnivorous Dinosauria in the United States National Museum, with special reference to the genera Antrodemus (Allosaurus) and Ceratosaurus. Bulletin of the United States National Museum 110:1-154.

Gutierrez K, and Sheldon ND. 2012. Paleoenvironmental reconstruction of Jurassic dinosaur habitats of the Vega Formation, Asturias, Spain. GSA Bulletin 124:596-610.

Hanson M, and Makovicky P. 2014. A new specimen of Torvosaurus tanneri originally collected by Elmer Riggs. Historical Biology 26:775-784.

Haq BU. 2018. Jurassic sea-level variations: a reappraisal. GSA Today 28: doi: 10.1130/GSATG359A.1

Hendrickx C, and Mateus O. 2014. Torvosaurus gurneyi n. sp., the largest terrestrial predator from Europe, and a proposed terminology of the maxilla anatomy in nonavian theropods. Plos One 9(3): e88905.

Hendrickx C, Mateus O, and Araújo R. 2015. The dentition of megalosaurid theropods. Acta Palaeontologica Polonica 60:627-642.

Hornung J, Böhme A, van der Lubbe T, Reich M, and Richter A. 2012. Vertebrate tracksites in the Obernkirchen Sandstone (late Berriasian, Early Cretaceous) of northwest Germanytheir stratigraphical, palaeogeographical, palaeoecological, and historical context. Palaeontologische Zeitschrift 86:231-267. 
915 Hübner T, and Rauhut OWM. 2010. A juvenile skull of Dysalotosaurus lettowvorbecki

916 (Ornithischia: Iguanodontia) and implications for cranial ontogeny, phylogeny and

917 taxonomy in ornithopod dinosaurs. Zoological Journal of the Linnean Society 160:366-

918396.

919 Huene Fv. 1926. The carnivorous Saurischia in the Jura and Cretaceous Formations, principally 920 in Europe. Revista del Museo de La Plata 29:35-167.

921 Kaever M, and Lapparent AFd. 1974. Les traces de pas de dinosaures du Jurassique de

922 Barkhausen (Basse Saxe, Allemagne). Bulletin de la Société Géologique de France

$923 \quad 16: 516-525$.

924 Kuhn O. 1958. Die Fährten der vorzeitlichen Amphibien und Reptilien. Bamberg: Verlagshaus 925 Meisenbach.

926 Lallensack J, Sander P, Knotschke N, and Wings O. 2015. Dinosaur tracks from the Langenberg 927 Quarry (Late Jurassic, Germany) reconstructed with historical photogrammetry: Evidence 928 for large theropods soon after insular dwarfism. Palaeontologia Electronica 18.2.31A: 192934.

930 Lapparent AFde. 1943. Les dinosauriens jurassique de Damparis (Jura). Memoires de la Société 931 géologique de la France, Nouvelle Série 47:5-20.

932 Lockley MG. 2009. New perspectives on morphological variation in tridactyl footprints: clues to 933 widespread convergence in developmental dynamics. Geological Quarterly 53:415-432.

934 Lockley MG, and Hunt AP. 1994. A track of the giant theropod dinosaur Tyrannosaurus from 935 close to the Cretaceous/Tertiary Boundary, northern New Mexico. Ichnos 3:213-218.

936 Lockley M, García-Ramos JC, Piñuela L, and Avanzini M. 2008. A comparative review of 937 vertebrate track assemblages from the Late Jurassic of Asturias, Spain and the western 938 939 USA: implications for faunal diversity in association with siliciclastic facies assemblages.

940 Lockley M, Lires J, García-Ramos JC, Piñuela L, and Avanzini M. 2007. Shrinking the world's 941 942 943 largest dinosaur tracks: Observations on the ichnotaxonomy of Gigantosauropus asturiensis and Hispanosauropus hauboldi from the Upper Jurassic of Asturias, Spain. Ichnos 14:247-255.

Lockley MG, Meyer CA, and Santos VF. 2000. Megalosauripus and the problematic concept of megalosaur footprints. Gaia 15:313-337. 
946 Lockley MG, Meyer C, Schulz-Pittman R, and Forney G. 1996. Late Jurassic dinosaur tracksites

947

948

949

950

951

952

953

954

955

956

957

958

959

960

961

962

963

964

965

966

967

968

969

970

971

972

973

974

975

976

from Central Asia: A preliminary report on the world's longest trackways. In: Morales M, ed. Continental Jurassic Symposium Volume. Museum Northern Arizona, Bulletin 60:137-140.

Lozano R, Delvene GM, Piñuela L, and García-Ramos JC. 2016. Late Jurassic biogeochemical microenvironments associated with microbialite-coated unionoids (Bivalvia), Asturias (Spain). Palaeogeography, Palaeoclimatology, Palaeoecology 443:80-97.

Madsen JH. 1976. Allosaurus fragilis: a revised osteology. Utah Geological and Mineralogical Survey Bulletin 109:3-163.

Madsen JH, and Welles SP. 2000. Ceratosaurus (Dinosauria, Theropoda). A revised osteology. Miscellaneous Publication, Utah Geological Survey 00-2:1-80.

Malafaia E, Dantas P, Ortega F, and Escaso F. 2007. Nuevos restos de Allosaurus fragilis (Theropoda: Carnosauria) del yacimiento de Andrés (Jurásico Superior; Centro-Oeste de Portugal). In: Cambra-Moo O, Martínez-Pérez C, Chamero B, Escaso F, de Esteban Trivigno S, and Marugán-Lobón J, eds. Cantera Paleontológica. Cuenca: Diputación Provincial de Cuenca, 255-271.

Malafaia E, Escaso F, Mocho P, Serrano-Martinez A, Torices A, Cachao M, and Ortega F. 2017b. Analysis of diversity, stratigraphic and geographical distribution of isolated theropod teeth from the Upper Jurassic of the Lusitanian Basin, Portugal. Journal of Iberian Geology 43:257-291.

Malafaia E, Mocho P, Escaso F, and Ortega F. 2017a. New data on the anatomy of Torvosaurus and other remains of megalosauroid (Dinosauria, Theropoda) from the Upper Jurassic of Portugal. Journal of Iberian Geology 43:33-59.

Malafaia E, Mocho P, Escaso F, and Ortega F. 2017c. Carcharodontosaurian evidence in the Upper Jurassic of Portugal: Filling the gap. Zitteliana 91:56-57.

Malafaia E, Ortega F, Escaso F, Dantas P, Pimentel N, Gasulla J, Ribeiro B, Barriga F, and Sanz J. 2010. Vertebrate fauna at the Allosaurus fossil-site of Andres (Upper Jurassic), Pombal, Portugal. Journal of Iberian Geology 36:193-204.

Malafaia E, Ortega F, Escaso F, and Silva B. 2015. New evidence of Ceratosaurus (Dinosauria: Theropoda) from the Late Jurassic of the Lusitanian Basin, Portugal. Historical Biology 27:938-946. 
977 Malafaia E, Ortega F, Escaso F, Silva B, Ramalheiro G, Dantas P, Moniz C, and Barriga F.

978

979

980

981

982

983

984

985

986

987

988

989

990

991

992

993

994

995

996

997

998

999

1000

1001

1002

1003

1004

1005

1006 2008a. Análisis preliminar de un nuevo ejemplar de Allosaurus del Grupo Lourinhã (Jurásico Superior de Torres Vedras, Portugal). In: Huerta P, and Torcida FernándezBaldor F, eds. Actas de las IV Jornadas Internacionales sobre Paleontología de Dinosaurios y su Entorno. Salas de los Infantes, Burgos: Colectivo Arqueológico y Paleontológico de Salas, 243-251.

Malafaia E, Ortega F, Silva B, and Escaso F. 2008b. Fragmento de un maxilar de terópodo de Praia da Corva (Jurásico Superior. Torres Vedras, Portugal). Palaeontologica Nova $8: 273-279$.

Manning P, Ott C, and Falkingham P. 2008. A probable tyrannosaurid track from the Hell Creek Formation (Upper Cretaceous), Montana, United States. Palaios 23:645-647.

Mannion P, Allain R, and Moine O. 2017. The earliest known titanosauriform sauropod dinosaur and the evolution of Brachiosauridae. Peerj 5:e3217.

Marquet P, and Taper M. 1998. On size and area: Patterns of mammalian body size extremes across landmasses. Evolutionary Ecology 12:127-139.

Martínez R, García-Ramos J, Piñuela L, Lires J, Luna M, and Veigas D. 2000. Vértebras caudales de Sauropoda y Theropoda (Dinosauria: Saurischia) del Jurásico Superior de Asturias, España. In: Diez J, and Balbino A, eds. I Congresso Ibérico de Paleontologia/XVI Jornadas de la Sociedad Española de Paleontología. Évora: Sociedad Española de Paleontología, 113-114.

Marty D, Ayer J, Becker D, Berger J, Billon-Bruyat J, Braillard L, Hug W, and Meyer CA. 2007. Late Jurassic dinosaur tracksites of the Transjurane highway (Canton Jura, NW Switzerland): overview and measures for their protection and valorisation. Bulletin für Angewandte Geologie 12:75-89.

Marty D, Belvedere M, Meyer CA, Mietto P, Paratte G, Lovis C, and Thuring B. 2010. Comparative analysis of Late Jurassic sauropod trackways from the Jura Mountains (NW Switzerland) and the central High Atlas Mountains (Morocco): implications for sauropod ichnotaxonomy. Historical Biology 22:109-133.

Marty D, Belvedere M, Razzolini NL, Lockley MG, Paratte G, Cattin M, Lovis C, and Meyer CA. 2017. The tracks of giant theropods (Jurabrontes curtedulensis ichnogen. \& ichnosp. 
1007

1008

1009

1010

1011

1012

1013

1014

1015

1016

1017

1018

1019

1020

1021

1022

1023

1024

1025

1026

1027

1028

1029

1030

1031

1032

1033

1034

1035

1036

1037 nov.) from the Late Jurassic of NW Switzerland: palaeoecological \& palaeogeographical implications. Historical Biology:doi.org/10.1080/08912963.08912017.01324438.

Mateus O. 2006. Late Jurassic dinosaurs from the Morrison Formation (USA), the Lourinha and Alcobaça Formations (Portugal), and the Tendaguru Beds (Tanzania): A comparison. New Mexico Museum of Natural History and Science Bulletin 36:1-9.

Mateus O, Walen A, and Antunes MT. 2006. The large theropod fauna of the Lourinha Formatuion (Portugal) and its similarity to that of the Morrison Formation, with a description of new species of Allosaurus. New Mexico Museum of Natural History and Science Bulletin 36:123-129.

Mateus O, and Milàn J. 2010. A diverse Upper Jurassic dinosaur ichnofauna from central-west Portugal. Lethaia, 43(2), 245-257.

Mazin J, Hantzpergue P, Bassoullet J, Lafaurie G, and Vignaud P. 1997. The Crayssac site (lower Tithonian, Quercy, Lot, France): discovery of dinosaur trackways in situ and first ichnological results. Comptes Rendus de l'Academie des Sciences, Serie II 325:733-739.

Mazin J, Hantzpergue P, and Olivier N. 2017. The dinosaur tracksite of Plagne (early Tithonian, Late Jurassic; Jura Mountains, France): The longest known sauropod trackway. Geobios 50:279-301.

Mazin J, Hantzpergue P, and Pouech J. 2016. The dinosaur tracksite of Loulle (early Kimmeridgian; Jura, France). Geobios 49:211-228.

McCrea R, Buckley L, Farlow J, Lockley M, Currie P, Matthews N, and Pemberton S. 2014. A 'terror of tyrannosaurs': The first trackways of tyrannosaurids and evidence of gregariousness and pathology in Tyrannosauridae. Plos One 9(7): e103613.

Méndez AH. 2014. The caudal vertebral series in abelisaurid dinosaurs. Acta Palaeontologica Polonica 59:99-107.

Mensink H, and Mertmann D. 1984. Dinosaurier-Fährten (Gigantosauropus asturiensis n.g. n.sp.; Hispanosauropus hauboldi n. g. n. sp.) im Jura Asturiens bei La Griega und Ribadesella (Spanien). Neues Jahrbuch für Geologie und Paläontologie, Monatshefte 1984(7):405-415.

Merino Tomé O, Suárez Rodríguez A, and Alonso JL. 2013. Mapa Geológico Digital continuo E. 1:50.000, Zona Cantábrica (Zona-1000). In: GEODE. Mapa Geológico Digital continuo de España. 
1038 Meyer CA. 2012. Dinosaur tracks in an ancient lower deltaic plain-interdistributary bay. In:

1039

1040

1041

1042

1043

1044

1045

1046

1047

1048

1049

1050

1051

1052

1053

1054

1055

1056

1057

1058

1059

1060

1061

1062

1063

1064

1065

1066

1067

1068

Richter A, and Reich M, eds. Dinosaur tracks 2011. An International Symposium, Obernkirchen, April 14-17, 2011. Abstract Volume and Field Guide to Excursions. Göttingen: Universitätsverlag, 43.

Meyer CA, and Thüring B. 2003. Dinosaurs of Switzerland. Comptes Rendus Palevol 2:103-117. Milàn J, Avanzini M, Clemmensen LB, García-Ramos JC, and Piñuela L. 2006. Theropod foot movement recorded from Late Triassic, Early Jurassic and Late Jurassic fossil footprints. In: Harris JD, Lucas SG, Spielmann J, Lockley MG, Milner ARC, and Kirkland JL, eds. The Triassic-Jurassic Terrestrial Transition. New Mexico Museum of Natural History and Science Bulletin 37:352-364.

Mocho P, Royo-Torres R, Escaso F, Malafaia E, Chaves C, Narvaez I, Perez-Garcia A, Pimentel N, Silva B, and Ortega F. 2017. Upper Jurassic sauropod record in the Lusitanian Basin (Portugal): Geographical and lithostratigraphical distribution. Palaeontologia Electronica 20.2.27A: $1-50$.

Moreau J, Neraudeau D, Vullo R, Abit D, Mennecart B, and Schnyder J. 2017. Late Jurassic dinosaur footprints from Chassiron-La Morelière (Oléron Island, western France). Palaeobiodiversity and Palaeoenvironments 97:773-789.

Niebuhr B, and Pürner T. 2014. Lithostratigraphie der Weißjura-Gruppe der Frankenalb (außeralpiner Oberjura) und der mittel- bis oberjurassischen Reliktvorkommen zwischen Straubing und Passau (Bayern). Schriftenreihe der Deutschen Gesellschaft für Geowissenschaften 83:5-72.

O'Connor PM. 2007. The postcranial axial skeleton of Majungasaurus crenatissimus (Theropoda: Abelisauridae) from the Late Cretaceous of Madagascar. Society of Vertebrate Paleontology, Memoir 8:127-162.

Olóriz F. 2002. Jurassic: Betic cordillera. In: Gibbons W, and Moreno T, eds. The geology of Spain. London: Geological Society, 235-237.

Olóriz F, Caracuel JE, Rodríguez-Tovar FJ, and Tavera JM. 2002. Upper Jurassic; Betic Cordillera. In: Gibbons W, and Moreno T, eds. The geology of Spain. London: Geological Society, 247-251.

Ortega F, Escaso F, Gasulla J, Dantas P, and Sanz J. 2006. Dinosaurios de la Península Ibérica. Estudios Geológicos 62:219-240. 
1069 Ostrom JH. 1978. The osteology of Compsognathus longipes Wagner. Zitteliana 4:73-118.

1070 Pérez-Moreno BP, Chure DJ, Pires C, Marques da Silva C, Dos Santos V, Dantas P, Póvoas L,

1071 Cachão M, Sanz JL, and Galopim de Carvalho AM. 1999. On the presence of Allosaurus

1072 fragilis (Theropoda: Carnosauria) in the Upper Jurassic of Portugal: first evidence of an

1073 intercontinental dinosaur species. Journal of the Geological Society 156:449-452.

1074 Peyer K. 2006. A reconsideration of Compsognathus from the Upper Tithonian of Canjuers,

1075 southeastern France. Journal of Vertebrate Paleontology 26:879-896.

1076 Pharisat A. 1993. Vertebres de dinosaure (Theropode) dans l'Oxfordien de Plaimbois-du-Miroir

1077 (Doubs). Societé d'Histoire Naturelle du Pays de Montbéliard 1993:191-192.

1078 Piñuela L, García-Ramos J, Romano M, and Ruiz-Omenaca J. 2016. First record of gregarious

1079 behavior in robust medium-sized Jurassic ornithopods: Evidence from the Kimmeridgian

1080 trackways of Asturias (N. Spain) and some general considerations on other medium-large

1081 ornithopod tracks in the Mesozoic record. Ichnos 23:298-311.

1082 Piñuela Suárez L. 2015. Huellas de dinosaurios y de otros reptiles del Jurásico Superior de

1083 Asturias Unpublished Ph.D.-thesis, University of Oviedo.

1084 Rauhut OWM. 2011. Theropod dinosaurs from the Late Jurassic of Tendaguru (Tanzania).

1085 Special Papers in Palaeontology 86:195-239.

1086 Rauhut OWM, Foth C, Tischlinger H, and Norell MA. 2012. Exceptionally preserved juvenile

1087 megalosauroid theropod dinosaur with filamentous integument from the Late Jurassic of

1088 Germany. Proceedings of the National Academy of Sciences 109:11746-11751.

1089 Rauhut OWM, Hübner TR, and Lanser K-P. 2016. A new megalosaurid theropod dinosaur from

1090 the late Middle Jurassic (Callovian) of north-western Germany: implications for theropod

1091 evolution and faunal turnover in the Jurassic. Palaeontologia electronica 19:1-65.

1092 Rauhut OWM, and Kriwet J. 1994. Teeth of a big theropod dinosaur from Porto das Barcas

1093 (Portugal). Berliner geowissenschaftliche Abhandlungen (E) 13:179-185.

1094 Rauhut OWM, and Tischlinger H. 2015. Archaeopteryx. In: Arratia G, Schultze H-P, Tischlinger H, and Viohl G, eds. Solnhofen Ein Fenster in die Jurazeit. Munich: Verlag Dr. Friedrich

1096 Pfeil, 491-507.

1097 Razzolini NL, Belvedere M, Marty D, Paratte G, Lovis C, Cattin M, and Meyer CA. 2017. Megalosauripus transjuranicus ichnosp. nov. A new Late Jurassic theropod ichnotaxon 
1099

1100

1101

1102

1103

1104

1105

1106

1107

1108

1109

1110

1111

1112

1113

1114

1115

1116

1117

1118

1119

1120

1121

1122

1123

1124

1125

1126

1127

1128

from NW Switzerland and implications for tridactyl dinosaur ichnology and ichnotaxomy. PLoS One 12(7):e0180289.

Razzolini NL, Oms O, Castanera D, Vila B, dos Santos V, and Galobart A. 2016. Ichnological evidence of megalosaurid dinosaurs crossing Middle Jurassic tidal flats. Scientific Reports 6:31494.

Remes K. 2006. Revision of the Tendaguru sauropod Tornieria africana (Fraas) and its relevance for sauropod paleobiogeography. Journal of Vertebrate Paleontology 26:651669.

Royo-Torres R, Cobos A, Luque L, Aberasturi A, Espilez E, Fierro I, Gonzalez A, Mampel L, and Alcala L. 2009. High European sauropod diversity during Jurassic-Cretaceous transition in Riodeva (Teruel, Spain). Palaeontology 52:1009-1027.

Ruiz-Omeñaca JI. 2010. Vertebrados fósiles (restos directos) de la Formación Vega. In: GarcíaRamos JC, ed. V Congreso del Jurásico de España. Guía de campo (excursión A). Las sucesiones margo-calcáreas marinas del Jurásico Inferior y las series fluviales del Jurásico Superior. Acantilados de la playa de Vega (Ribadesella). Colunga: Museo del Jurásico de Asturias, 64-68.

Ruiz-Omeñaca JI, Pereda Suberbiola X, Piñuela L, and García-Ramos JC. 2013. First evidence of stegosaurs (Dinosauria: Thyreophora) in the Vega Formation, Kimmeridgian, Asturias, N Spain. Geogaceta 53:37-40.

Ruiz-Omeñaca JI, Piñuela L, and García-Ramos J. 2007. Una vértebra de un pequeño ornitópodo (Dinosauria: Ornithischia) del Kimmeridgiense (Formación Lastres) de Tazones (Villaviciosa, Asturias). Geogaceta 45:83-86.

Ruiz-Omeñaca JI, Piñuela L, and García-Ramos JC. 2008. Primera evidencia de dinosaurios diplodocinos (Sauropoda: Diplodocidae) en el Jurásico Superior de Asturias (Noreña ). In: Ruiz-Omeñaca JI, Piñuela L, and García-Ramos JC, eds. Libro de resúmenes XXIV Jornadas de la Sociedad Española de Paleontología Museo del Jurásico de Asturias (MUJA), Colunga, 15-18 de octubre de 2008.

Ruiz-Omeñaca JI, Piñuela L, and García-Ramos J. 2009b. Nuevos restos de ornitópodo (Ornithischia: Ankylopollexia) del Jurásico Superior de Tazones, Asturias (Formación Tereñes). Geogaceta 45:59-62. 
1129 Ruiz-Omeñaca JI, Piñuela L, and García-Ramos J. 2010. El primer diente de ornitópodo del 1130 Jurásico Superior de España (Asturias). Geogaceta 48:83-86.

1131 Ruiz-Omeñaca JI, Piñuela L, and García-Ramos J. 2012. New ornithopod remains from the 1132 Upper Jurassic of Asturias (North Spain). In: Royo-Torres R, Gascó F, and Alcalá L, eds. 10th Annual Meeting of the European Association of Vertebrate Palaeontologists. Teruel: Fundación Conjunto Paleontológico de Teruel - Dinópolis, 219-222.

Stein K, Csiki Z, Curry Rogers K, Weishampel DB, Redelstorff R, Carballido JL, and Sander

Ruiz-Omeñaca JI, Piñuela L, García-Ramos JC, and Canudo JI. 2009c. Dientes de dinosaurios carnívoros (Saurischia: Theropoda) del Jurásico Superior de Asturias. In: Hurtado PH, and Torcida F, eds. Actas de las IV Jornadas Internacionales sobre Paleontología de Dinosaurios y su Entorno. Salas de los Infantes: Colectivo Arqueológico y Paleontológico de Salas, 273-291.

Ruiz-Omeñaca JI, Piñuela L, García-Ramos J, and Pereda Suberbiola X. 2009a. A Dacentrurinae stegosaur from the Late Jurassic of Asturias (Northern Spain). Journal of Vertebrate Paleontology, Program and Abstracts 29:174A.

Sadleir R, Barrett PM, and Powell HP. 2008. The anatomy and systematics of Eustreptospondylus oxoniensis, a theropod dinosaur from the Middle Jurassic of Oxfordshire, England. Monograph of the Palaeontographical Society 160:1-82.

Sander PM, Mateus O, Laven T, and Knötschke N. 2006. Bone histology indicates insular dwarfism in a new Late Jurassic sauropod dinosaur. Nature 441:739-741.

Santos VF, Moratalla JJ, and Royo-Torres R. 2009. New sauropod trackways from the Middle Jurassic of Portugal. Acta Palaeontologica Polonica, 54(3), 409-422.

Schudack U, and Schudack M. 2002. New biostratigraphical data for the Upper Jurassic of Asturias (northern Spain) based on Ostracoda. Revista Española de Micropaleontología 31:1-18.

Sereno PC, Wilson JA, Larsson HCE, Dutheil DB, and Sues H-D. 1994. Early Cretaceous dinosaurs from the Sahara. Science 266:267-271. PM. 2010. Small body size and extreme cortical bone remodeling indicate phyletic dwarfism in Magyarosaurus dacus (Sauropoda: Titanosauria). Proceedings of the National Academy of Sciences 107:9258-9263. 
1159 Stromer E. 1915. Ergebnisse der Forschungsreisen Prof. E. Stromers in den Wüsten Ägyptens. II. 1160 Wirbeltierreste der Baharije-Stufe (unterstes Cenoman). 3. Das Original des Theropoden Spinosaurus aegyptiacus nov. gen., nov. spec. Abhandlungen der Königlich Bayerischen Akademie der Wissenschaften, Mathematisch-physikalische Klasse 28:1-32.

Taylor MP. 2009. A re-evaluation of Brachiosaurus altithorax Riggs 1903 (Dinosauria, Sauropoda) and its generic separation from Giraffatitan brancai (Janensch 1914). Journal of Vertebrate Paleontology 29:787-806.

Thierry J, Barrier E, Abbate E, Alekseev A, Ait-Ouali R, Ait-Salem H, Bouaziz S, Canerot J, Georgiev G, Guiraud R, Hirsch F, Ivanik M, Le Metour J, Le Nindre YM, Medina F, Mouty M, B N, Nikishin A, Page K, Panov D, A P, Poisson A, Sandulescu M, Sapunov I, Seghedi A, Soussi M, Tchoumatchenko P, Vaslet D, Vishnevskaya V, Volozh Y, Voznezenski A, Walley C, Wong T, Ziegler M, Ait-Brahim L, Bergerat F, Bracene R, Brunet M, Cadet J, Guezou J, Jabaloy A, Lepvrier C, and Rimmele G. 2000. Early

Tischlinger H, Göhlich UB, and Rauhut OWM. 2015. Raubdinosaurier (Theropoda). In: Arratia Tithonian. In: Dercourt J, Gaetani M, Vrielynck B, Barrier E, Biju-Duval B, Brunet M, Cadet J, Crasquin S, and Sandlescu M, eds. Atlas Peri-Tethys, Palaeogeographical maps.

Vrielynck B, and Bouysse P.,2003. The changing face of the earth. Paris: Commission for the Geological Map of the World. CCGM-UNESCO Publishing.

Walker AD. 1964. Triassic reptiles from the Elgin area: Ornithosuchus and the origin of carnosaurs. Philosophical Transactions of the Royal Society of London, Series B 248:53134.

Wellnhofer P. 2008. Archaeopteryx. Der Urvogel von Solnhofen. Munich: Verlag Dr. Friedrich Pfeil. Formation (Brushy Basin Member), west-central New Mexico. Museum of Northern Arizona Bulletin 60:73-79. 
1188 Ziegler PA. 1988. Evolution of the Arctic North Atlantic and the Western Tethys. AAPG Memoir $1189 \quad 43: 1-198$. 


\section{Figure 1}

Geological map of the eastern Asturian sector, including the location of Vega beach (Ribadesella).

Modified after Merino-Tomé et al. (2013).

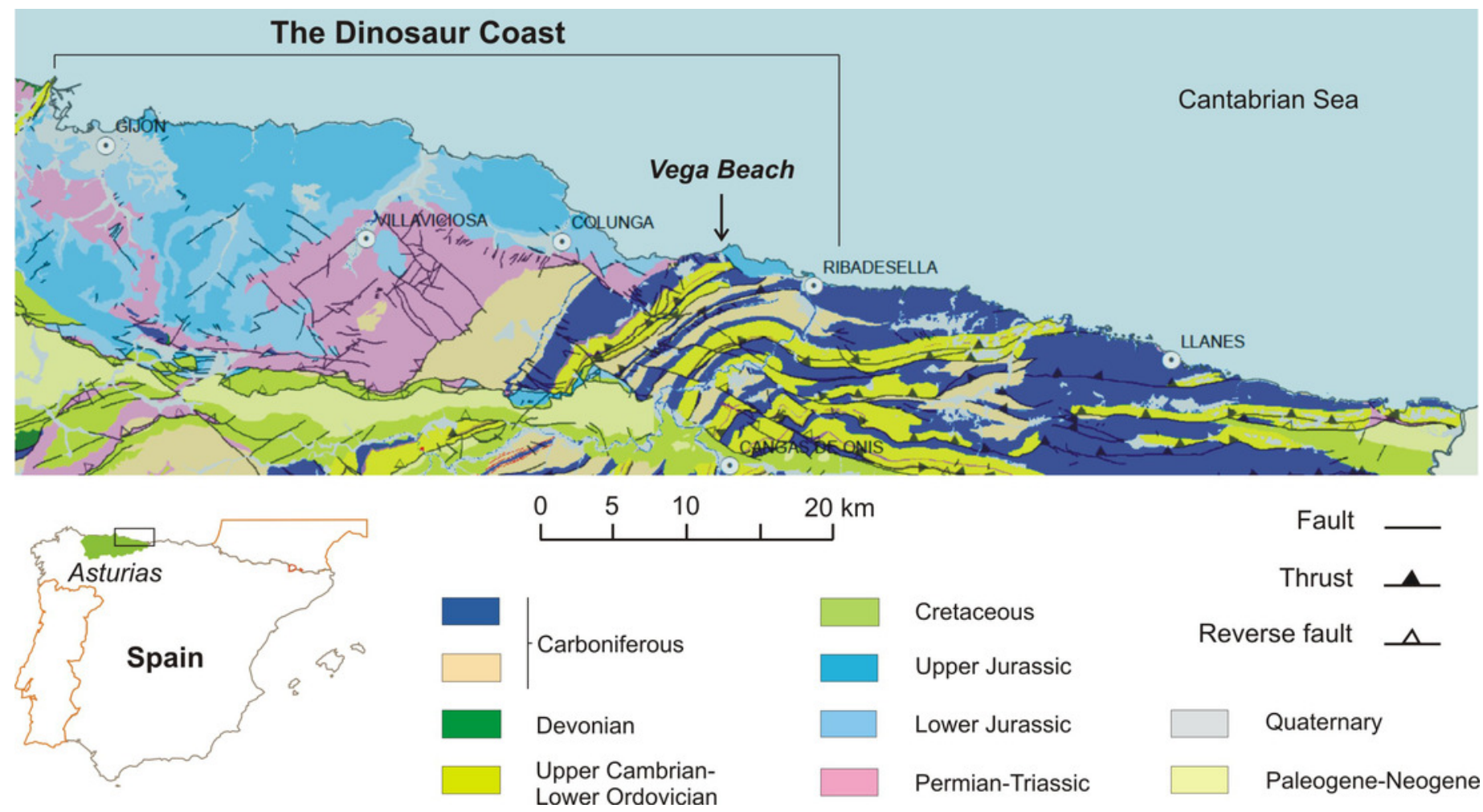


Figure 2

Geology of the Asturian Jurassic.

A, General stratigraphic log of the Asturian Jurassic along the Tazones-Ribadesella sector. Not to scale. Modified after García-Ramos et al. (2011). B, Detailed log of the lower part of the Vega Formation (after García-Ramos et al., 2010c). The level where the vertebra was found is indicated by an asterisk. 
A

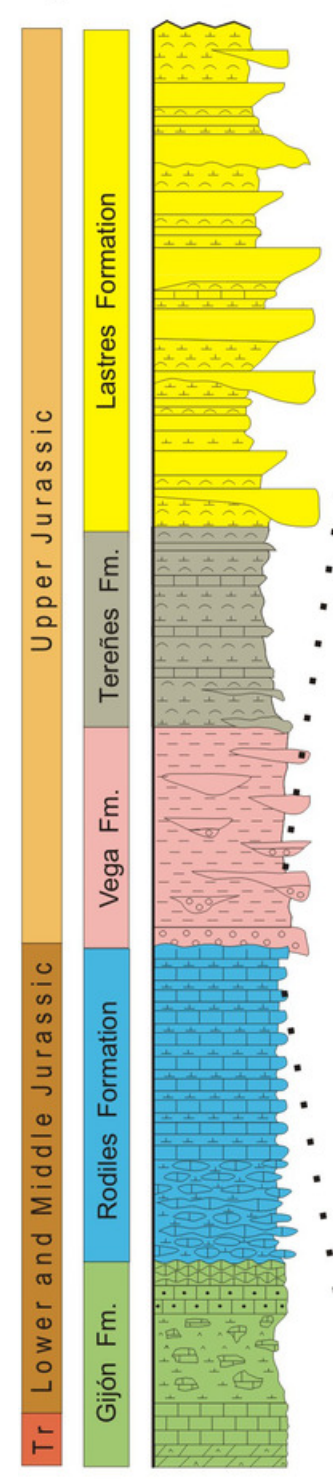

$\because \circ$ Siliceous

$\square$ Sandstones

ヘーA Grey shelly

Nodular grey

limestones

--_- Red mudstones

Grey marls

대매 Layered grey

Z7 Grey dolomites

Peer] reviewing PDF

\section{:}$$
:
$$

B

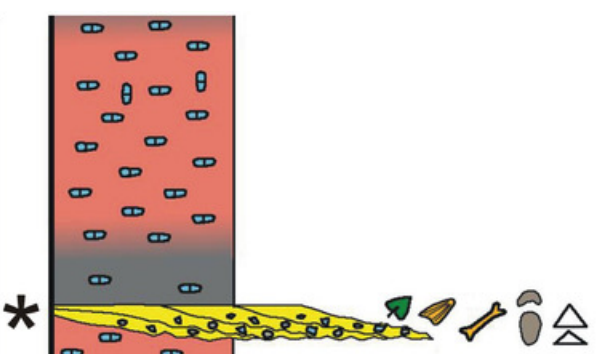

-

$$
\text { . } 40
$$$$
\text { - }
$$ 


\section{Figure 3}

Tip of a large megalosaurid tooth from the Vega Formation.

A, general view in lingual or labial view. B, detail of distal serrations and anastomosing enamel ornamentation. Scale bars are $10 \mathrm{~mm}$. Photographs by Oliver Rauhut and Diego Castanera.

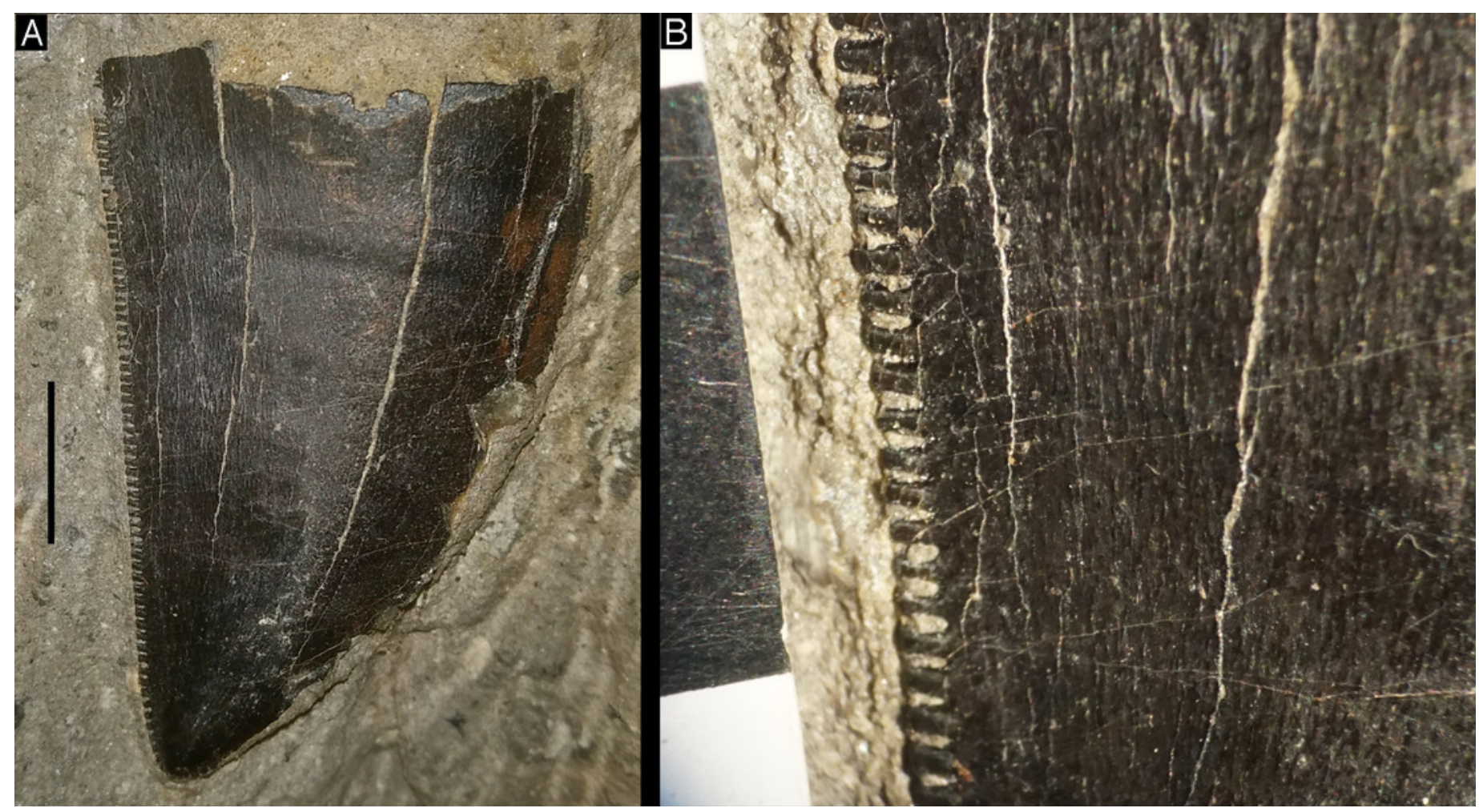




\section{Figure 4}

Anterior caudal vertebra of a giant megalosaurid from the Vega Formation, MUJA-1913.

A, left lateral view. B, posterior view. C, ventral view. D, dorsal view. ch, chevron facet; $d$, depression on anterior end of dorsal surface of transverse process; I, lamina dividing the conical postzygocentrodiapophyseal fossa from a shallow dorsal depression; pcd, pleurocentral depression; pcdf, postzygocentrodiapophyseal fossa; pcdl, posterior centrodiapophyseal lamina; vg, ventral groove. Scale bar is $50 \mathrm{~mm}$. Photographs by Oliver Rauhut and Diego Castanaera. 

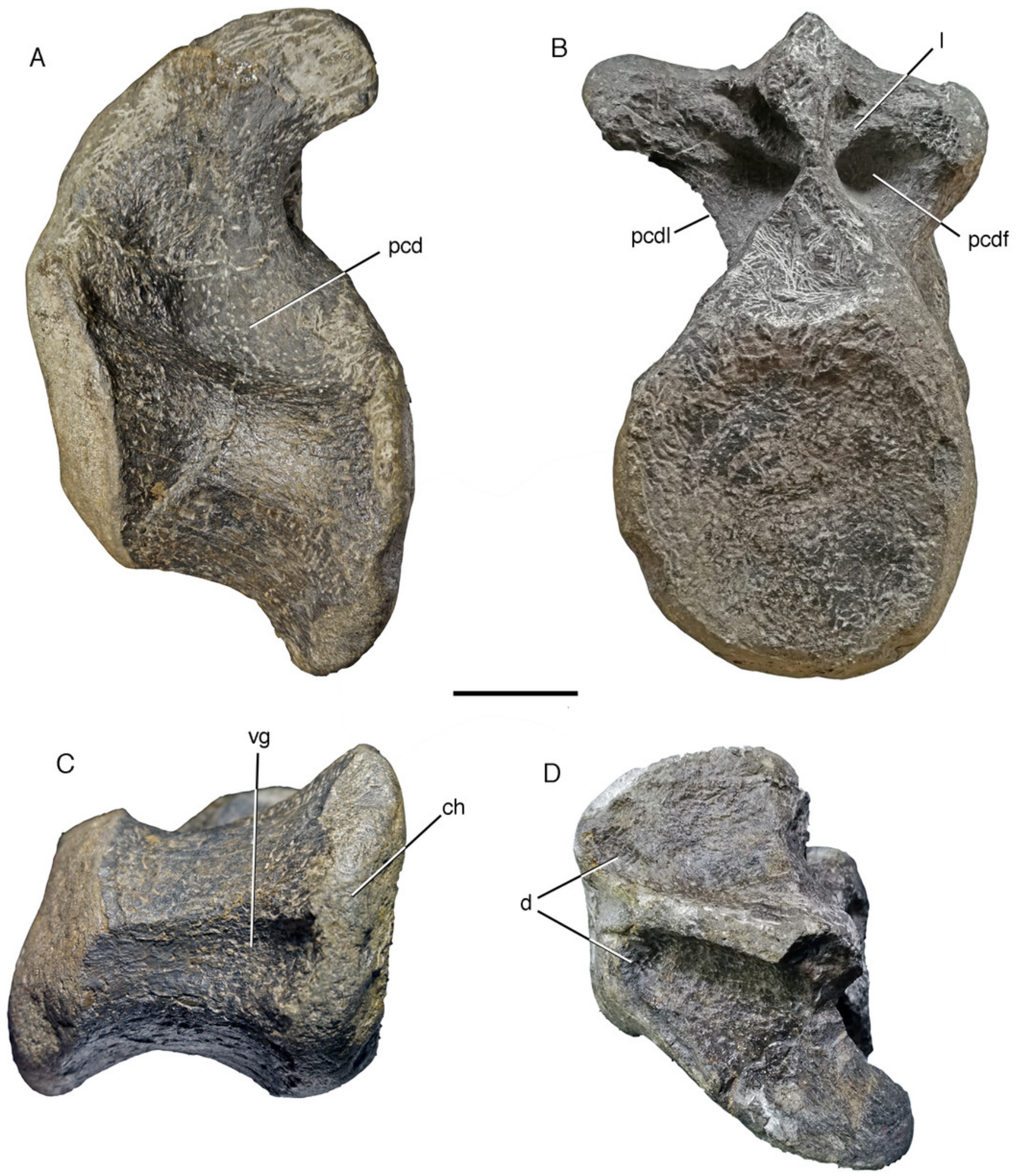


\section{Figure 5}

Asturian Jurassic footprints with a weak mesaxony and probably related to very large or giant megalosaurid theropod trackmakers (Morphotype A).

A, B and C specimens still on Argüero, Oles and Tazones sea cliffs, respectively. Note that track $\mathrm{C}$ does not preserved the end of the digit IV. D, MUJA-1889. E-H, same specimens, photographs with outline drawings to better illustrate track morphology. Photographs by José-Calros García-Ramos.

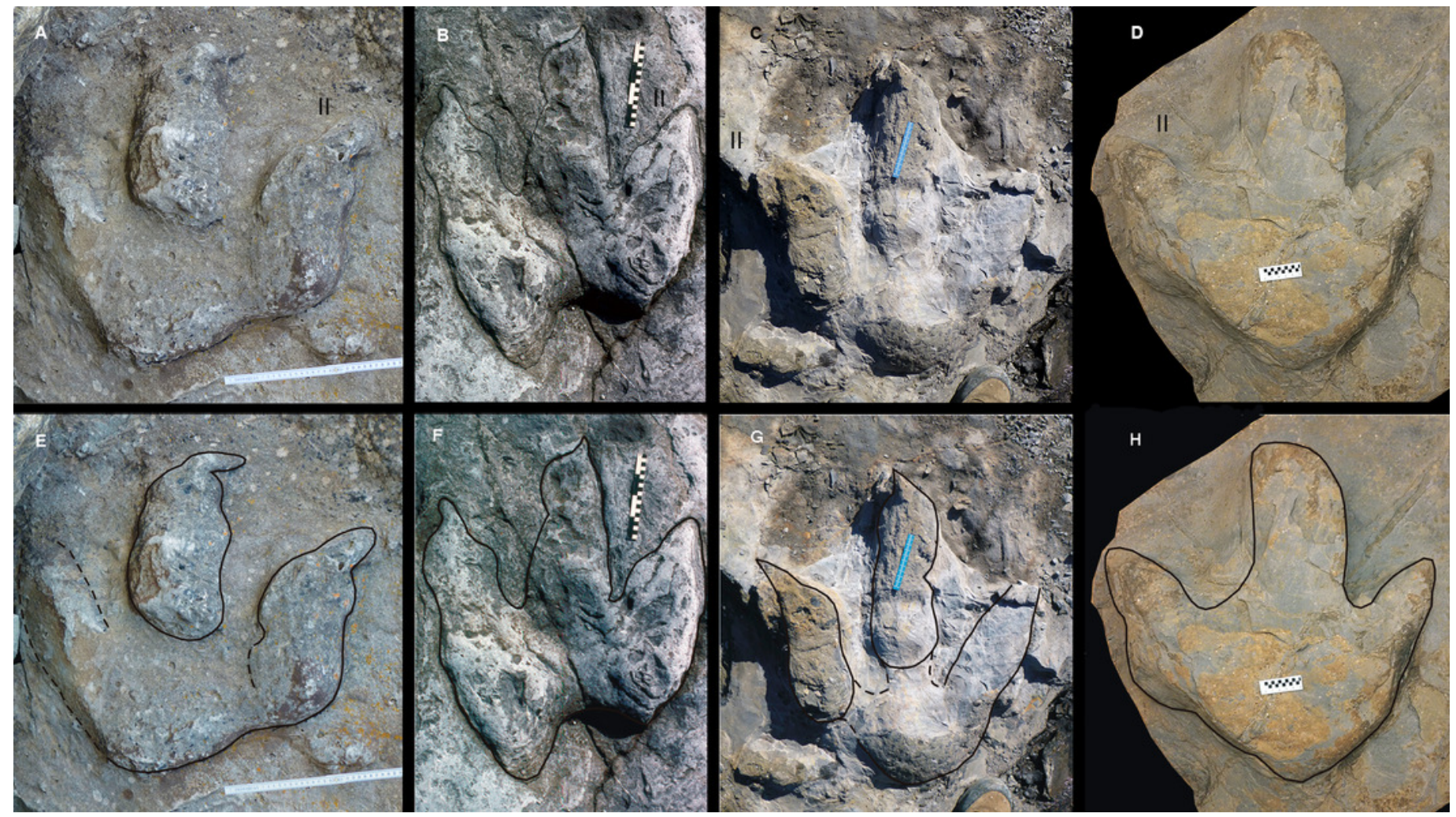




\section{Figure 6}

Giant Asturian Jurassic footprints, strongly mesaxonic (Morphotype B).

A, MUJA-1263. B, MUJA-0213, scale bar: 1 m. C, specimen still on Argüero sea cliffs. D-F, same specimens, photographs with outline drawings to better illustrate track morphology.

Photographs by José-Calros García-Ramos. 


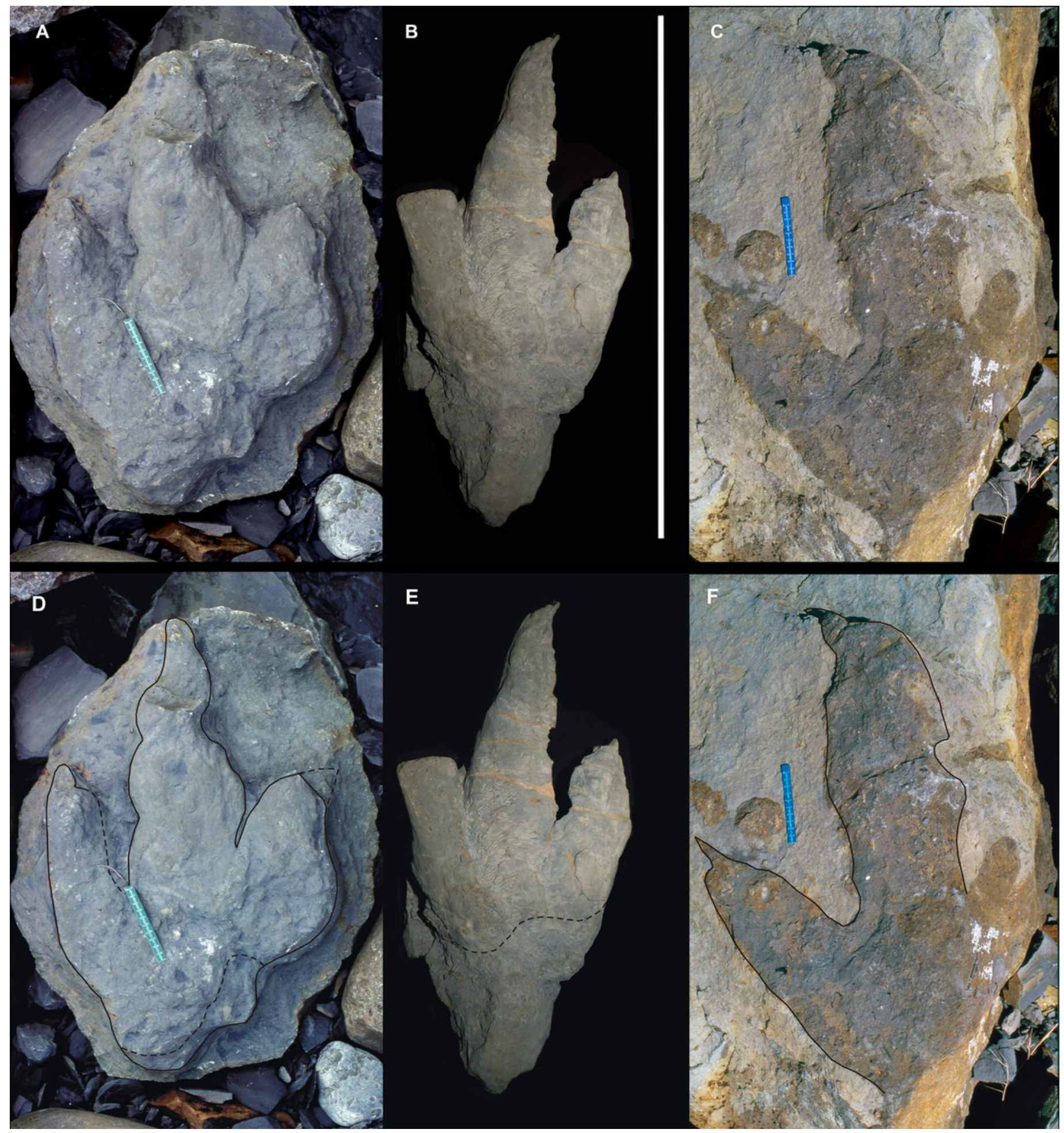




\section{Table $\mathbf{1}$ (on next page)}

Measurements of the Asturian tracks.

R (Right foot) L (Left foot) FL (Footprint length), WL (Footprint width), II^IV total divarication angle. For the specimens see Figs. 5 and 6. 
1 Table 1

2

\begin{tabular}{|l|c|c|c|c|c|}
\hline Morphotype A & Foot & FL & WL & FL/WL & II^IV \\
\hline Argüero & $\mathrm{R}$ & 62 & 70 & 0.88 & 36 \\
\hline Oles & $\mathrm{L}$ & 82 & 66 & 1.24 & 38 \\
\hline Tazones & $\mathrm{L}$ & 57 & $>47$ & $>1.16$ & 38 \\
\hline MUJA-1889 & $\mathrm{L}$ & 53 & 53 & 1 & 40 \\
\hline Morphotype B & & & & & \\
\hline MUJA-1263 & $\mathrm{R}$ & 62 & 38 & 1.63 & 15 \\
\hline MUJA-0213 & $\mathrm{R}$ & 78 & & & \\
\hline Argüero & $\mathrm{R}$ & 67 & & & \\
\hline
\end{tabular}

3 